\title{
A especialização do advogado em violência doméstica
}

\author{
The lawyer's specialization in domestic violence
}

\author{
EMANUEL CARVALHO' \\ emanuelcarvalho-44900p@adv.oa.pt
}

GALILEU - REVISTA DE DIREITO E ECONOMIA - e-ISSN 2184-1845

Volume XXI $\cdot 1^{\text {st }}$ January Janeiro $-30^{\text {TH }}$ June Junho $2020 \cdot$ pp. 111-141

DOI: http://doi.org/10.26619/2184-1845.XXI.1.5

Submitted on March $23^{\text {th }}, 2020$. Accepted on June $4^{\text {th }}, 2020$

Submetido em 23 de Março, 2020 - Aceite a 4 de junho, 2020

RESUMO A erosão do tecido social português provocado pela violência doméstica é actual, complexa e inquietante. Urge apreender o fenómeno e avoca-se, fundamentalmente, para observação a dimensão técnico-jurídica, tão determinante para garantir a tutela efectiva da vítima. Identifica-se, por sua vez, a meta-especialização em violência doméstica pelos profissionais, que (em rede) amparam a vítima - em particular, do advogado -, como desígnio de asseverar-se a evolução político-jurídica vigente rumo à afirmação da advocacia como profissão baluarte na tutela dos direitos, liberdades e garantias fundamentais da vítima. Pensar na especialização do advogado em violência doméstica é um desafio, sinuoso entre proficuidades e percalços, que sendo bem-sucedido sobreleva o espírito e missão da advocacia para o altar do humanismo.

PALAVRAS-CHAVE violência doméstica; tutela da vítima; técnico de apoio à vítima; advogado especialista.

ABSTRACT In Portugal, the erosion of social fabric caused by domestic violence is current, complex and unsettling. It's priority to understand that phenomenon and about that, technical-legal angle will be, essentially, the field of observation because is so important to guarantee the effective protection of the victim. Then, the analysis of meta-specialization in domestic violence by professionals, who, in cooperated, support the victim - in particular, the lawyer - is the purpose to ensure the current political-legal development towards the affirmation of advocacy as a beacon profession for safeguarding basic rights, freedoms and legal guarantees of victim's. Thinking about the lawyer's specialization in domestic

1 Advogado desde 2006. Doutorando em direito pela Universidade Autónoma de Lisboa desde 2018. Jurista em casa de abrigo de vítimas de violência doméstica desde 2017 
violence is a serious challenge in a winding itinerary, with many twists and turns, which, if will successfully, elevates the spirit and mission of advocacy to the altar of humanism. KEYWORDS domestic violence; rights of victim; victim support technician; expert lawyer.

\section{Intróito}

Hoje e mais do que em qualquer outro período passado, urge a especialização do advogado em violência doméstica, sendo que consubstancia um desafio seriamente exigente para a profissão. Existirão, seguramente, advogados exímios na profissão, existirão profissionais extraordinários na prestação de apoio à vítima de violência doméstica e existirão, diferentes daqueles, os advogados especialistas em violência doméstica, focando-se entre estes especialmente os que patrocinam a pessoa lesada.

A competência, disponibilidade e ponderação são chaves mestras para uma intervenção eficaz e efectiva por parte do advogado junto da vítima, sendo mister que tais traços se estendam igualmente aos inúmeros profissionais que integram a cadeia operacional existente para a protecção da vítima ${ }^{2}$. Noutro prisma, a vítima obtém confiança, segurança e, até, conforto diante do advogado que evidencia conhecimento de causa e experiência aprofundada sobre a temática, e promove uma concretização imediata dos direitos "especiais"3 que lhe assistem, alicerçado num patrocínio sagaz e pragmático, bem como ajustado e tendo em conta o contexto vivencial envolvente.

Há, assim, um elo fundamental que aproxima, ainda que de modo oposto, o advogado da vítima de violência doméstica. Ao primeiro, como à Ordem dos Advogados, compete promover a tutela dos direitos, liberdades e garantias fundamentais das pessoas e, assim, contribuir para a sustentação do nosso Estado de direito democrático ${ }^{4}$. Para a vítima é conditio sine qua non que a referida tutela seja efectiva de modo a que, por um lado, o estado de vulnerabilidade e desigualdade que a consome seja comutado por um ambiente de paz, liberdade e saúde. E por outro, o cepticismo que paira sobre a eficiência do sistema judicial e que, malogradamente, continua a constituir uma razão de desmotivação para a vítima

2 Ex: polícias, procuradores do Ministério Público, juízes, médicos, enfermeiros, professores, educadores sociais, professores, psicólogos, terapeutas familiares, assistentes sociais, et caetera.

3 A atribuição do estatuto de vítima é conditio sine qua non para aquela exercer os direitos vertidos no "regime jurídico aplicável à prevenção da violência doméstica, à protecção e à assistência das suas vítimas", aprovado pela Lei n. ${ }^{0} 112 / 2009$, publicada em Diário da República, $1 .^{a}$ série - N. ${ }^{\circ} 180$ - 16 de Setembro de 2009.

4 Artigo $2 .^{\circ}$ da Constituição da República Portuguesa (CRP) e artigo $3 .^{\circ}$, alínea a) do Estatuto da Ordem dos Advogados (EOA). 
denunciar o crime às autoridades seja de vez afastado e, assim, se contribua para a almejada mudança de mentalidade com o desígnio de, no futuro, a tolerância ser igual a zero diante de uma situação de violência doméstica.

Nesta esteira, eleva-se a simbiose entre o advogado e a vítima dado que se tem reconhecido socialmente a nobreza e a audácia daquele profissional em tomar frequentemente a iniciativa de promover as contendas judiciais que visem proteger plenamente a dignidade da pessoa humana constitucionalmente consagrada. Sendo que por vezes, mais frequente do que raro, o advogado tem de actuar singularmente ou, comummente, "contra a maré", e demonstrar mesmo a sua máxima resiliência porquanto essas batalhas implicam a obrigação de percorrer diversas instâncias jurisdicionais, internas e internacionais, com o tempo que aquelas usualmente muito consomem.

Ademais, a vítima encontra-se, habitualmente, isolada das suas relações de confiança por força da actuação do agressor, sobressaindo-se daquelas as pessoas com as quais possua vínculo familiar, profissional ou pessoal. Como tal, a vítima carece vitalmente de suporte profissional que seja, sobretudo, pela sua constância e confiabilidade capaz de assumir-se como uma espécie de referência suficientemente motivadora para a mesma quebrar definitivamente o ciclo de violência.

Em suma, o papel do advogado representa para a vítima de violência doméstica uma espécie de reduto de defesa indispensável (sendo, por vezes, mesmo o derradeiro) para aquela obter o afastamento do agente do crime. De todo o modo, o apoio prestado pelo advogado deve ser promovido, de preferência, num contexto de cooperação interprofissional com as diferentes entidades que constituem a malha institucional de protecção da vítima.

\section{Problemática}

A violência doméstica é um flagelo social extremamente complexo que dificulta a padronização do perfil do agressor ou da vítima. Admite-se, em tese, que aquela pode ser infligida por qualquer pessoa, independentemente da sua origem, residência permanente, cultura, língua, religião, instrução, capacidade económica, profissão, religião, idade, orientação sexual, saúde, et caetera ${ }^{5}$, sem descurar que na praxis os indicadores divulgados pelas autoridades conduzem ao traçar de características predominantes que marcam a vítima ou o agente do crime.

5 Carvalho, Emanuel - «Violência doméstica e estrangeiros em Portugal». In: Galileu - Revista de Direito e Economia, Volume XX, 1. ${ }^{\circ}$ semestre 2019, p. 123. 
No que respeita em particular à qualidade profissional inerente ao advogado, esta não configura excepção à possibilidade de ser vítima ou agressor. Em detalhe, os conhecimentos superiores na área do direito e, até, do modus operandi da prática judiciária, detidos pelo advogado, muito acrescidos face ao comum dos cidadãos, não o dota de meios de defesa que o tornem imune, assim como não o inibe de praticar o crime, sendo que neste último caso até o pode (lamentavelmente) apetrechar de técnicas para aquele ser concretizado de modo a que as provas sejam de difícil (para não afirmar, de impossível) obtenção ou mesmo ilícitas.

Atenta a referida complexidade, observar os indicadores respeitantes à violência doméstica configura um precioso meio para apreender o fenómeno. Contudo, é importante ter consciência que essa ferramenta, focando-se nos casos reportados, vai ficar sempre aquém da realidade e, consequentemente, da verdadeira quantidade e gravidade das situações ocorridas.

Ainda assim, os indicadores denunciadores da violência doméstica em Portugal revelam dados manifestamente inquietantes e têm, por isso, merecido uma intervenção do legislador, bem como uma frequente e ampla cobertura pelos mass media (se bem que esta tenha sido concretizada em tons muito alarmistas ${ }^{6}$ ). Ao passo que se tem tornado numa temática debatida frequentemente na nossa sociedade, desde contextos informais até científicos.

Oficialmente, os dados mais recentes (isto é, de 27/03/2020) divulgados pela Direcção-Geral de Reinserção e Serviços Prisionais, no Portal do Governo Português, dão conta que a criminalidade associada à violência doméstica registada no $4 .^{\circ}$ trimestre do ano 2019 ampliou face ao anterior período homólogo ${ }^{7}$. O relatório sintetiza que se verificou um aumento:

- dos reclusos, quer em prisão efectiva $(+14,1 \%)$, quer em prisão preventiva $(+80,4 \%)$;

- da aplicação de medidas de coacção de afastamento, ora com vigilância electrónica $(+63,1 \%)$, ora sem aquele controle $(+24,2 \%)$;

6 A violência doméstica tem merecido um amplo destaque nos meios de comunicação social portugueses dada a gravidade e frequência dos casos enquadrados nesse tipo de situações. Recentemente, a Entidade Reguladora para a Comunicação (ERC) divulgou um estudo - denominado "Representações da Violência Doméstica nos telejornais de horário nobre" - mediante o qual concluiu, globalmente, que aquela temática não foi abordada, em diversas ocasiões, de modo adequado e apresentou um conjunto de recomendações para os referidos meios evitarem exposições que conduzam a uma espécie de sensacionalismo noticioso (consultado a 01/05/2020). Disponível em: https://www.flipsnack.com/ERCpt/representa-es-viol-ncia-dom-stica-nos-telejornais-de-hnobre/ full-view.html.

7 Comunicado do Governo Português com os dados da criminalidade associada à violência doméstica registados no $4 .{ }^{\circ}$ trimestre do ano 2019 (consultado a 01/05/2020) Disponível em: https://www.portugal.gov.pt/downloadficheiros/ficheiro.aspx?v=8edoc295-dic7-4c67-be38-a179413ade57. 
- de pessoas sujeitas a programas de reabilitação para agressores ${ }^{8}(+28,2 \%)$;

- de vítimas de violência doméstica apoiadas por meios técnicos de teleassistência $(+52,4 \%)$.

Do mesmo relatório resulta que, no ano 2019, as autoridades receberam 29.473 participações enquadradas no crime de violência doméstica, o que revela uma média aproximada de 87 sinalizações por dia ou de 3 casos por hora. E, face ao ano precedente, verificou-se um aumento de $11,5 \%$ de participações, dado que foram registados 26.483 casos, conforme consta também do Relatório Anual de Segurança Interna referente ao ano $2018^{9}$.

Ainda que resulte do referido relatório um ligeiríssimo decréscimo de vítimas mortais, designadamente de 37, em 2018, para 35, em 2019 (se bem que, no plano do género feminino, verificou-se o inverso, tendo aumentado de 24 para 26), é factor de elevada consternação social ter ocorrido uma média de 2 a 3 homicídios por mês.

É certo que a média do morticínio é impactante, porém não se deve menosprezar toda as demais formas que constituem violência doméstica porque os efeitos negativos decorrentes, por exemplo, de abusos sexuais, actos de tortura, violência psicológica ou emocional, privações de liberdade ou isolamento social forçado podem consubstanciar danos irreparáveis e com sequelas prolongadas ao longo da vida da vítima.

A par dos registos públicos têm emergido relatórios divulgados por organizações não-governamentais (ONG's) ${ }^{10}$, que se dedicam a apoiar as vítimas de crimes, abrangendo as situações de violência doméstica. Estes registos representam uma mais-valia complemen-

8 Em Portugal, a reabilitação dos agressores consubstancia uma resposta judicial muito recente (identificandose como pioneiros o programa "Contigo" aplicado desde 2009 nos Açores e desde 2010 em Cascais), ao invés dos sistemas judiciais norte-americano e do Reino Unido que vêm desenvolvendo essa intervenção desde a década de 70 e 80 do século passado. Neste sentido consultar: Rijo, Daniel; CAPINHA, Marta - «A reabilitação dos agressores conjugais: dos modelos tradicionais de reabilitação ao Programa Português para Agressores de Violência Doméstica (PAVD)». In: Ousar Integrar - Revista de Reinserção Social e Prova, Ano 5, n. ${ }^{0}$ 11, Jan. 2012, pp. 83 a 97.

Identificam-se teoricamente diferentes modelos de intervenção - tais como, modelos cognitivocomportamentais, modelos psicodinâmicos, modelos de ventilação ou modelos de interação - e chama-se à colação um dos modelos cognitivo-comportamentais mais populares nesta área designado por programa "Duluth", quiçá, pelos resultados prácticos satisfatórios decorrentes da sua aplicação (consultado em 01/05/2020). Disponível em: https://www.theduluthmodel.org/wheels/. Apreciar em detalhe o referido programa mediante consulta de: CARvalHo, Emanuel - «Violência doméstica ...». In: Galileu - Revista de Direito e Economia, Volume $\mathrm{XX}, 1 .{ }^{\circ}$ semestre 2019, p. 128.

9 Direcção-Geral de Política de Justiça - Relatório Anual de Segurança Interna de 2018, página 17 (consultado a 01/05/2020). Disponível em: https://www.portugal.gov.pt/download-ficheiros/ficheiro.aspx?v=ad5cfe37-od52$412 \mathrm{e}-83 \mathrm{fb}-7$ fog $8448 \mathrm{dba} 7$.

10 Destacam-se do universo das organizações não-governamentais, que se manifestam activamente contra a violência doméstica, a Associação Ilga Portugal (AIP), a Associação de Mulheres Contra a Violência (AMCV), a Associação Portuguesa de Apoio à Vítima (APAV), a Associação Portuguesa de Mulheres Juristas (APMJ) e a União de Mulheres Alternativa e Resposta (UMAR). 
tar aos dados oficiais porque, habitualmente, reportam dados temporalmente recentes e retratam com elevada minudência os perfis das pessoas agressoras e ofendidas com o intuito de descreverem os contextos e as características das dinâmicas da violência doméstica.

Entre estes últimos registos não-oficiais chama-se à colação o "Relatório Preliminar (01 de Janeiro a 12 de Novembro de 2019)", divulgado pelo Observatório de Mulheres Assassinadas da União de Mulheres Alternativa e Resposta. Este relatório revela terem ocorrido naquele período 27 tentativas de femicídio e detalha que 28 dos 30 femicídios aconteceram em contexto de relações de intimidade e familiares ${ }^{11}$.

Conjugando-se os indicadores oficiais com os relatos das ONG's amplia-se o retrato da violência doméstica em Portugal (admitindo-se que qualquer pequena divergência existente entre os indicadores constitua um mal menor) e, assim, potencia-se a evolução de implementação de normas, medidas e até prácticas que contribuam para prevenção do fenómeno, protecção da vítima e efectiva responsabilização do autor do crime.

\section{Conceitualização}

No ordenamento jurídico português, a violência doméstica obteve (somente) expressão em 2007 com a tipificação legal do respectivo crime, mediante a vigésima terceira alteração ao Código Penal ${ }^{12}$ (CP), introduzida pela Lei n. ${ }^{0}$ 59/2007 ${ }^{13}$. Em detalhe, a referida lei inseriu uma redacção integralmente nova ao artigo $152 .^{\circ}$ do $\mathrm{CP}$, desde a sua epígrafe, consagrando literalmente a expressão "Violência Doméstica", até ao corpo da norma.

O texto normativo, que vigorava até essa alteração legal, foi projectado para o artigo subsequente, embora o legislador tenha optado apenas por uma espécie de renumeração alfabética e tenha atribuído ao tipo legal de crime de "Maus tratos" o artigo 152. ${ }^{\circ}$-A. É seguro afirmar que este último artigo foi criado ex novo pela referida alteração ao $\mathrm{CP}$, contudo ao absorver maioritariamente o teor do anterior artigo $152 . .^{\circ}$, que tinha por epígrafe "Maus tra-

11 O referido relatório revela que "entre 2004 e 12 de Novembro de 2019 o Observatório de Mulheres Assassinadas (OMA) registou um total de 531 vítimas de femicídio nas relações de intimidade (RI) e relações familiares (RF) e 618 vítimas de tentativa de femicídio nas RI e RF" - página 2 (consultado a 01/05/2020). Disponível em: http:// www.umarfeminismos.org/images/stories/oma/Relat\%C3\%B3rio_OMA_2019.pdf.

12 O CP foi aprovado pelo Decreto-Lei n. ${ }^{\circ} 400 / 82$ e publicado em Diário da República, $1 .^{\mathrm{a}}$ série, $1 .^{\circ}$ suplemento N. ${ }^{\circ} 221-23$ de Setembro de 1982, somando até ao presente mais de 40 alterações.

13 A Lei n. ${ }^{\circ}$ 59/2007 foi publicada em Diário da República, $1 .^{a}$ série - N. ${ }^{\circ} 170$ - 4 de Setembro de 2007. 
tos e infracção de regras de segurança"14, provocou uma mudança atípica na sistematização do CP porquanto fez antepor a forma de crime especial face ao crime geral ${ }^{15}$.

Retomando o artigo $152 .^{\circ}$ do CP em vigor, que já contou com duas alterações desde $2007^{16}$, contém - no seu n. ${ }^{\circ} 1$ - o que se pode considerar como sendo uma definição legal de violência doméstica ${ }^{17}$. Porém, importa ter presente que tal definição, sendo de natureza penal, foi construída tendo subjacente o princípio da intervenção mínima ou ultima ratio da política criminal imposta pelo artigo $18 .^{\circ},{ }^{\circ} .^{\circ} 2$ da Constituição da República Portuguesa (CRP), esta enquanto fonte de legitimação material da lei penal ${ }^{18}$.

Mais tarde, em 2013, por força de Portugal ter sido o primeiro Estado da União Europeia a aderir ${ }^{19}$ à "Convenção do Conselho de Europa para a Prevenção e o Combate à Violência contra as Mulheres e a Violência Doméstica", comummente assinalada por Convenção de Istambul, passou a estar internacionalmente vinculado a esse instrumento e, por conseguinte, vigora, desde então, no nosso ordenamento jurídico mais uma definição de violência doméstica ${ }^{20}$.

Realçada a Convenção de Istambul não se deve preterir que esse instrumento representa uma materialização dos princípios basilares consagrados na Declaração Universal dos Direitos Humanos (DUDH), a qual pela mesma razão apontada possui plena efectivi-

14 DiAs, Figueiredo - Comentário Conimbricense do Código Penal - Tomo I. Coimbra, Coimbra Editora, 1999, p. 332.

15 Albuguerque, Paulo Pinto de - Comentário do Código Penal à luz da Constituição da República e da Convenção Europeia dos Direitos do Homem. Lisboa: Universidade Católica Editora, 2015, pp. 588 a 596.

16 A redacção imposta ao artigo $152 .^{\circ}$ do CP pela Lei $n .^{\circ}$ 59/2007 foi sujeita a duas alterações legais. A primeira introduzida pela Lei n. ${ }^{\circ}$ 19/2013, publicada em Diário da República, $1 .^{\text {a }}$ série - N. ${ }^{\circ} 37$ - 21 de fevereiro de 2013 , e a segunda pela Lei n. ${ }^{\circ}$ 44/2018, publicada em Diário da República, $1 .^{\text {a }}$ série - N. ${ }^{\circ} 153$ - 9 de Agosto de 2018.

17 Artigo $152 .^{\circ}$

Violência doméstica

1 - Quem, de modo reiterado ou não, infligir maus tratos físicos ou psíquicos, incluindo castigos corporais, privações da liberdade e ofensas sexuais:

a) Ao cônjuge ou ex-cônjuge;

b) A pessoa de outro ou do mesmo sexo com quem o agente mantenha ou tenha mantido uma relação de namoro ou uma relação análoga à dos cônjuges, ainda que sem coabitação;

c) A progenitor de descendente comum em $1 .{ }^{\circ} \mathrm{grau}$; ou

d) A pessoa particularmente indefesa, nomeadamente em razão da idade, deficiência, doença, gravidez ou dependência económica, que com ele coabite;

é punido com pena de prisão de um a cinco anos, se pena mais grave lhe não couber por força de outra disposição legal.

18 BRANDÃo, Nuno - «Bem Jurídico e Direitos Fundamentais entre a Obrigação Estadual de Protecção e a Proibição do Excesso». In: Estudos em Homenagem ao Prof. Doutor Manuel da Costa Andrade. Coimbra: Instituto Jurídico, 2017, página 239-266.

19 Por Decreto do Presidente da República n. ${ }^{0}$ 13/2013, publicado em Diário da República, $1 .^{a}$ série $-~ N .^{\circ} 14-21$ de janeiro de 2013, foi "ratificada a Convenção do Conselho da Europa para a Prevenção e o Combate à Violência contra as Mulheres e a Violência Doméstica, adotada em Istambul, a 11 de maio de 2011, aprovada pela Resolução da Assembleia da República n. ${ }^{\circ}$ 4/2013, em 14 de dezembro de 2012."

20 Artigo $8 .^{\circ}$, n. ${ }^{\circ} 2$ da CRP. 
dade no nosso ordenamento jurídico ${ }^{21}$, segundo a qual todas as pessoas são livres e iguais em dignidade, devendo as relações assentar num espírito de fraternidade ${ }^{22}$. Nesta esteira, a referida convenção reflecte, ainda, os ditames contemplados ora na Convenção Europeia dos Direitos Humanos (CEDH), ora na Carta dos Direitos Fundamentais da União Europeia (CDFUE) dado que ambas enaltecem a dignidade do ser humano ${ }^{23}$.

Apreciando-se, agora, o artigo $152 .^{\circ}$ do $\mathrm{CP}$, a par do artigo $3 .^{\circ}$, alínea b ${ }^{24}$, da Convenção de Istambul, constata-se uma significativa similitude conceitual. Contudo, qualquer divergência existente, atenta a coexistência e vigência de ambas as normas no nosso ordenamento, deve merecer uma interpretação subjugada ao princípio da unidade do sistema jurídico ${ }^{25}$.

Da conjugação dos elencados preceitos torna-se, assim, viável construir um conceito de violência doméstica mais robusto. E desta harmonização identifica-se em comum que a violência doméstica subdivide-se entre uma dimensão subjectiva - assente na relação existente entre a pessoa que controla ou exerce poder sobre outra, isto é, entre o agente do crime e a ofendida - e uma dimensão objectiva - composta pelas condutas que preenchem a sua ilicitude.

Na dimensão objectiva, a violência doméstica pauta-se por um comportamento lesivo singular ou reiterado ${ }^{26}$. Ainda que o iter criminis usual em situações de violência doméstica seja aquele desenvolvido por acções sistemáticas e repetidas infligidas pelo agente do crime sobre a vítima, o legislador foi claro em impor censura sobre qualquer acto grave ainda que este seja denunciado como uma conduta singular.

21 Artigo $8 .^{\circ}$, n. $^{\circ} 1$ da CRP.

22 Artigo $1 .^{\circ}$ da DUDH, proclamada pela Resolução n. ${ }^{\circ}$ 217-A da Assembleia-Geral das Nações Unidas, de 10/12/1948.

23 Preâmbulo da CEDH (assinada pelo Conselho da Europa em 04/11/1950, ratificada pela Lei n. ${ }^{\circ}$ 65/78, publicada em Diário da República I Série, n. ${ }^{\circ} 236$, de 13/10/1978) e artigo $1 .^{\circ}$ da CDFUE (publicado no Jornal Oficial da União Europeia n. ${ }^{\circ} \mathrm{C} 83$ de 30/03/2010).

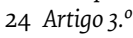

\section{Definições}

b) «"violência doméstica" designa todos os actos de violência física, sexual, psicológica ou económica que ocorrem no seio da família ou do lar ou entre os actuais ou ex-cônjuges ou parceiros, quer o infractor partilhe ou tenha partilhado, ou não, o mesmo domicílio que a vítima»

25 Artigo $9 .^{\circ}$, n. ${ }^{\circ}$ 1, do Código Civil (CC).

26 A jurisprudência tem considerado que, após a entrada em vigor da Lei n. ${ }^{\circ}$ 59/2007 que introduziu no nosso ordenamento o tipo legal de crime de violência doméstica, foi dissipada a querela que pairava sobre o anterior artigo $152 .^{\circ}$ do CP - "Maus Tratos" - dado que a actual redacção do artigo é expressa em considerar que, para o preenchimento do mencionado tipo de crime, pode ser suficiente a práctica de um só acto ou pode ocorrer com a repetição de condutas ilícitas. Conferir neste sentido os seguintes arestos: Acórdão do Tribunal da Relação de Guimarães, no processo n. ${ }^{\circ}$ 639/08.6GBFLG.G1, de 15/10/2002; Acórdão do Tribunal da Relação de Lisboa, no processo n. ${ }^{\circ}$ 3/16.oPAPST.L1-9, de 01-06/2017; Acórdão do Tribunal da Relação de Coimbra, no processo n. ${ }^{\circ}$ 1290/12.1PBAVR.C1, de 29/01/2004 (consultado a 01/05/2020). Disponível em: http://www.dgsi.pt). 
Na mesma dimensão, a violência doméstica pode ser traçada pelo tipo de dano provocado na vítima, sendo que pode afectar a sua saúde - física e psicológica - e a sua condição socioeconómica.

Em pormenor, o legislador reprova, primeiro, comportamentos que lesem a integridade física da pessoa, independentemente da intenção (negligência ou dolo) ou intensidade (simples ou grave) do seu autor.

Segundo, o legislador censura ofensas de natureza verbal (por exemplo, a injúria) que afectem a vítima no plano psíquico ou emocional.

Terceiro, o legislador desaprova as condutas que coartem a liberdade e a autonomia da vítima, quer aquelas sejam enquadradas no condicionamento da sua independência, quer assumam um modo de coacção sobre a vítima para agir contra a sua vontade.

Quarto, o legislador condena a violação da liberdade sexual da vítima.

Quinto (e último), o legislador proíbe condutas que desrespeitem a autonomia financeira da vítima e sujeitem esta ao isolamento social ${ }^{27}$.

Na dimensão subjectiva, a violência doméstica assenta em relações pessoais, podendo estas assumir o grau de parentesco (por exemplo, a relação entre cônjuges ou entre pais e filhos, embora a relação entre o progenitor e descendente em linha recta não deva ir além do primeiro grau), ou não (por exemplo, unidos de facto ou numa relação de namoro).

É consabido que a relação entre cônjuges, assumindo o marido o papel de agressor e a esposa o papel de vítima, constituiu a forma em que a violência doméstica mais ocorre, quer à escala global, quer em Portugal. De todo o modo e por força do princípio da igualdade está tutelada a defesa de todas as pessoas, independentemente do género do agressor ou da vítima, contemplando-se expressamente os mesmos direitos para as pessoas lésbicas, gays, bissexuais, transexuais, intersexuais, et caetera.

O legislador decidiu conferir à dimensão subjectiva uma amplitude elevada ao prever, por um lado, que a violência doméstica pode ocorrer em circunstâncias de coabitação, ou não, entre o alegado agressor e a vítima. Neste sentido e a partir da alteração ao $\mathrm{CP}$ ocor-

27 A jurisprudência tem afirmado recorrentemente que a violência doméstica pode configurar-se mediante uma "agressão económica" e, em exemplo, dessa dimensão autónoma tem sido decidido que se preenche o tipo legal previsto no artigo $152 .^{\circ}$ quando o comportamento do agente impossibilita a ofendida de gerir os seus rendimentos. Conferir neste sentido os seguintes arestos: Acórdão do Tribunal da Relação de Coimbra, no processo n. ${ }^{0}$ 663/16.5PBCTB.C1, de 07/02/2018, e o Acórdão do Tribunal da Relação de Guimarães, no processo n. ${ }^{\circ}$ 201/16.06GBBCL.G1, de 06/02/2017 (consultado a 01/05/2020). Disponível em: http://www.dgsi.pt/).

Em sentido diferente, o Professor e Magistrado Pinto de Albuquerque afirma que a agressão financeira "deve ser subsumida aos maus-tratos psíquicos, isto é, a uma particular modalidade de violência psicológica em consonância com o conceito amplo de violência doméstica da Convenção de Istambul". Conferir nota 7 do artigo $152 .^{\circ}$ da obra citada na nota de rodapé $n .^{\circ} 15$. 
rida em 2013, a tutela da vítima passou a abranger as relações de namoro ${ }^{28}$. E por outro, ao atribuir uma tutela particular às vítimas que estejam numa situação de especial vulnerabilidade em função da "idade, deficiência, doença, gravidez ou dependência económica".

Assente a conceitualização de violência doméstica, importa agora reflectir sobre os bens jurídicos tutelados pelo artigo $152 .^{\circ}$ do CP. Neste âmbito, o pensamento doutrinal e a jurisprudência não convergem e, em síntese, apontam-se as principais posições.

No entendimento do professor Taipa de Carvalho, a par de demais ilustres penalistas, o bem jurídico tutelado centra-se na saúde da vítima. No entanto, refere tratar-se de um bem jurídico complexo uma vez que considera englobar a saúde física e psicológica. E, na situação particular dos menores, defende mesmo que serão ilícitas as condutas que impossibilitem ou restrinjam o desenvolvimento normal e saudável daqueles ${ }^{29}$.

O professor e magistrado Pinto de Albuquerque defende uma multi-tutela de bens, desde a integridade física e psíquica, passando pela liberdade pessoal e, liberdade e autodeterminação sexual, até à honra ${ }^{30}$.

Nos tribunais portugueses tem sido, ainda, preconizado que o artigo $152 .{ }^{\circ}$ do $\mathrm{CP}$ visa tutelar não só a saúde, mas igualmente a integridade pessoal, que merece dignidade constitucional conforme o seu artigo $25{ }^{\circ 31}$.

De todo o modo, seja por força da tutela da dignidade humana ${ }^{32}$ ou da integridade pessoal $^{33}$, o bem ou os bens jurídicos tutelados pela referida norma penal encontram expressão e protecção na nossa Lei Fundamental.

Em remate, a estatuição da violência doméstica desdobrada entre normas de cariz nacional e transnacional exige ao advogado (e demais profissionais que actuem nesta área) uma

28 A Lei n. ${ }^{\circ}$ 19/2013, conferiu à alínea b), do n. ${ }^{\circ}$ 1, do artigo $152 .^{\circ}$ do $\mathrm{CP}$ a seguinte redacção: b) A pessoa de outro ou do mesmo sexo com quem o agente mantenha ou tenha mantido uma relação de namoro ou uma relação análoga à dos cônjuges, ainda que sem coabitação. (sublinhado nosso) Afastando-se, assim, a versão anterior nos seguintes termos: b) A pessoa de outro ou do mesmo sexo com quem o agente mantenha ou tenha mantido uma relação análoga à dos cônjuges, ainda que sem coabitação.

29 Carvalho, Taipa de - «Artigo $152 .{ }^{\circ}$ do CP». In: Comentário Conimbricense do Código Penal - Tomo I, Coimbra: Coimbra Editora, 1999, p. 332. Comungam desta posição: SÁ GomEs, Catarina - O Crime de Maus Tratos Físicose Psíquicos Infligidos ao Cônjuge ou ao Convivente em Condições Análogas às dos Cônjuges, Lisboa: AAFDL, 2004, página 59; FernANDES, Plácido Conde - «Violência Doméstica: novo quadro penal e processual penal». In: Revista do CEJ, n. ${ }^{\circ}$ 8, Lisboa, 2004, p. 305; Garcia, M. Miguez, Rio, J. M. Castela - Código Penal Anotado. Coimbra: Almedina, 2015, em notas ao artigo $152 .^{\circ}$. Conferir os seguintes arestos: Acórdão do Tribunal da Relação do Porto, processo n. ${ }^{\circ}$ 176/11.1SLPRT.P1, de 26/09/2012 e o Acórdão do Tribunal da Relação de Coimbra, processo. n. ${ }^{\circ}$ 182/06.8TAACN, de 19/11/2008 (consultado a 01/05/2020). Disponível em: http://www.dgsi.pt/.

30 Conferir nota 2 da obra citada na nota de rodapé $n .{ }^{\circ} 15$.

31 Conferir o ponto I do sumário do Acórdão do Tribunal da Relação de Lisboa, processo n. ${ }^{\circ}$ 3/16.oT.L1-9, citado na nota de rodapé $n .^{\circ} 26$.

32 Artigo $1 .^{\circ}$ da CRP. CANotilho, Gomes e Moreira, Vital - Constituição da República Portuguesa Anotada Artigos $1 .^{\circ} a$

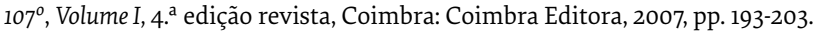

33 Artigo $25 \cdot^{\circ}$, n. ${ }^{\circ} 1$ da CRP. 
intervenção técnica complexa e exigente. Por outro prisma, uma intervenção profissional menos rigorosa conduz a uma diminuição do exercício dos direitos, liberdades e garantias fundamentais que se quer plena na assistência da vítima, sendo que no caso particular da vítima de violência doméstica contribuiu para o enfraquecimento da sua posição que, por essência, já é débil.

\section{Tutela da vítima de violência doméstica}

A tutela da vítima da violência doméstica em Portugal emergiu, em 2007, por via da introdução do respectivo tipo legal de crime no CP. A inserção do crime de violência doméstica no catálogo do $\mathrm{CP}$ não veio colmatar uma lacuna legal e deve ser apreciada como uma tutela especial, embora essa opção legislativa possa consubstanciar um reflexo do designado fenómeno da "hiper-criminalização" ${ }^{34}$. Com isto se pretende afirmar que a conduta passível, desde então, de preencher os elementos previstos no artigo $152 .^{\circ}$ do CP merecia anteriormente tutela penal, ainda que para o efeito uma acção pudesse ser subsumida simultaneamente a diferentes tipos legais de crime (tais como a ofensa à integridade física, a injúria, a ameaça, entre outros).

A criminalização da violência doméstica abriu caminho para uma sucessiva e múltipla legiferação tendente a contribuir para a macro erradicação do presente flagelo social e para a protecção individual da vítima. Neste sentido, começa-se por destacar a Lei n. ${ }^{0} 112 / 2009^{35}$, dado ter consagrado um regime jurídico focado especificamente na prevenção da violência doméstica e, na protecção e assistência das respectivas vítimas".

O referido regime provocou uma alteração substancial no nosso ordenamento jurídico e constituiu, antecipa-se, uma manifesta optimização no desígnio para o qual foi projectado, dado que traçou e concentrou, estruturadamente, uma tutela politica-jurídico-criminal em abono da vítima de violência doméstica.

Em detalhe, sobressai-se, primeiro, a obrigação governamental de elaboração de um "Plano Nacional Contra a Violência Doméstica" (PNCVD) ${ }^{36}$ e, de promoção pela educação e sensibilização-informação da sociedade sobre a presente temática ${ }^{37}$.

34 A possibilidade de uma conduta ser subsumida, simultaneamente, a diferentes tipos legais de crime pode dar azo ao denominado fenómeno da "hiper-criminalização". E no que respeita, por exemplo, à tutela da "integridade física", enquanto bem jurídico, aquela não deve oscilar em função da relação entre o agente do crime e a pessoa ofendida. VAlente, Manuel Monteiro Guedes - Direito Penal do Inimigo e o Terrorismo. Coimbra: Almedina, 2017, p. 21.

35 Conferir nota de rodapé n. ${ }^{\circ} 3$.

36 Artigos $3 .^{\circ}$, alínea g) e $4 .^{\circ}$, n. ${ }^{\circ} 1$ da Lei n. ${ }^{\circ} 112 / 2009$.

37 Artigos $3 .^{\circ}$, alínea a), $77 .^{\circ}$ e $78 .^{\circ}$ da Lei n. ${ }^{\circ} 112 / 2009$. 
Segundo, a possibilidade das autoridades atribuírem um estatuto de vítima ${ }^{38}$, que confere um conjunto considerável de direitos exclusivos à vítima, embora determinadas prerrogativas poderão manter-se após a cessação do estatuto ${ }^{39}$.

Terceiro, a previsão de um serviço complementar de teleassistência que a vítima pode accionar em qualquer instante, leia-se, em modo de socorro ${ }^{40}$.

E, por fim, a definição de medidas e direitos projectados para garantir a máxima protecção policial, bem como a tutela judicial e social da vítima ${ }^{41}$, que se justificam pela sua relevância apreender-se de imediato ainda com mais minúcia.

No âmbito da protecção policial realça-se a intervenção das autoridades mediante a apresentação de um plano de segurança - com orientações de autoprotecção - ajustado à situação vivencial de cada vítima ${ }^{42}$. E por outro, a obtenção de prova no mais breve período de tempo (sem exceder as 72 horas) é um procedimento capital para a tomada das medidas de protecção à vítima e as medidas de coacção ao arguido mais adequadas ${ }^{43}$.

Neste domínio poder-se-ia apresentar mais prerrogativas pro bono da vítima, porém e sem menosprezo pelas mesmas, o que se revela peculiar na intervenção policial é medir onde esta é verdadeira e positivamente impactante na vida da vítima.

Se há exemplo distinto no seio da intervenção policial é o caso afecto à concretização do direito de recuperação dos bens e pertences da vítima, retidos habitualmente na residência onde permanece o agressor e fruto daquela não ter tido oportunidade ou capacidade para planear uma saída de casa. Ainda que a lei apenas preveja a presença policial quando seja efectivamente necessária, as autoridades policiais têm no "terreno" revelado progressivamente, maior voluntariedade no acompanhamento da vítima à residência ${ }^{44}$. Sem preterir a consabida limitação dos recursos humanos das autoridades, bem como o constrangimento no serviço que a disponibilidade para esse acompanhamento pode causar, não soçobra dúvida que uma diligência desta natureza sem a presença policial consubstancia uma abordagem perigosa para a integridade da vítima. Ademais, a mediação policial é pre-

38 No seguimento do disposto no artigo 83. ${ }^{\circ}$, n. ${ }^{\circ} 1$ da Lei n. ${ }^{\circ} 112 / 2009$, foi publicada a Portaria n. ${ }^{\circ} 229-\mathrm{A} / 2010 \mathrm{em}$ Diário da República, $1 .^{\text {a }}$ série, $1 .^{\circ}$ Suplemento - N. ${ }^{\circ} 79-23$ de Abril de 2010, mediante a qual foram aprovados "os modelos de documentos comprovativos da atribuição do estatuto de vitima". O Despacho n. ${ }^{\circ}$ 7108/2011, publicado em Diário da República, 2. ${ }^{a}$ série, - N. ${ }^{0} 91$ - 11 de Maio de 2011, estabeleceu "os critérios de atribuição do estatuto de vítima, pela Comissão para a Cidadania e a Igualdade de Género, à vítima de violência doméstica".

39 Artigos $14 .^{\circ}$, n. $^{\circ} 3$ e $24 .^{\circ}$, n. ${ }^{\circ} 3$ da Lei n. ${ }^{\circ} 112 / 2009$.

40 Artigos $20 .^{\circ}$, n. $^{\circ} 5$ e $35 .^{\circ}$, n. ${ }^{\circ} 3$ da Lei n. ${ }^{\circ} 112 / 2009$. No seguimento destes normativos foi publicada a Portaria n. ${ }^{\circ}$ 220-A/2010 em Diário da República, $1 .^{\text {a }}$ série, $1 .^{\circ}$ Suplemento - N. ${ }^{\circ} 74-16$ de Abril de 2010, mediante a qual foram estabelecidas "as condições de utilização inicial dos meios técnicos de teleassistência" e os "meios técnicos de controlo à distância".

41 Secção II (artigos $25 .^{\circ}$ a $40 .^{\circ}$ ) e Secção III (artigos $41 .^{\circ}$ a $52 . .^{\circ}$ ) do Capítulo IV da Lei n. ${ }^{\circ} 112 / 2009$.

42 Artigo $27 .^{\circ}-\mathrm{A}, \mathrm{n} . .^{\circ} 2$ da Lei n. ${ }^{\circ} 112 / 2009$.

43 Artigo 29. ${ }^{\circ}$-A, n. ${ }^{\circ} 1$ da Lei n. ${ }^{\circ} 112 / 2009$.

44 Artigo $21 .^{\circ}$, n. $^{\circ} 4$ da Lei n. ${ }^{\circ} 112 / 2009$. 
ponderante para a efectivação da restituição dos bens, o que por si só confere dignidade à posição da vítima (sem negligenciar pela indispensabilidade da vítima ter acesso a bens estritamente pessoais ou essenciais para cuidados de saúde), como representa uma acção em que o agressor sendo intimado in loco a respeitar os direitos da vítima contribuiu para o restabelecimento da igualdade entre ambos, sob pena de ser detido em flagrante delito pela tentativa ou práctica de qualquer delito.

No domínio da tutela judicial ressaltam-se as declarações para memória futura ${ }^{45} \mathrm{e}$, o recurso à videoconferência ou à teleconferência ${ }^{46}$. A primeira é um procedimento probatório que pode ocorrer na fase de inquérito, em ambiente informal, reservado e, desde que autorizado pelo tribunal, com a presença de um técnico de apoio à vítima ou outro profissional que preste apoio à vítima. É consabido que este tipo de prova potencia a dispensabilidade da presença da vítima em sede de audiência de julgamento. Considerando que essa exoneração afasta a designada revitimização secundária da vítima - tão peculiar nesta forma de violência ${ }^{47}$ e, in casu, provocada habitualmente por ser sujeita a recontar os factos denunciados e, concomitantemente, a reviver memórias traumatizantes -, torna-se imperioso ponderar mais assiduamente o seu recurso.

Por sua vez, o recurso à videoconferência ou à teleconferência, marcado pelo depoimento da vítima ser concretizado à distância, constituiu um meio de prova abonador da serenidade e consequente objetividade testemunhal, bem como garantidor da segurança na deslocação ao tribunal e do sigilo acerca do paradeiro da vítima, eliminando qualquer modo de perseguição. Pelas mais-valias descritas em prol da vítima, este é um procedimento probatório que é recomendável ser amplamente requerido, do mesmo modo que a eventual objecção deve merecer uma fundamentação minuciosa, quer de direito quer de facto, da obrigação presencial da vítima. Nesta esteira, sendo a vítima compelida a comparecer na audiência de julgamento e, portanto, inevitável a possibilidade de confronto com o arguido, impunha-se a tomada oficiosa do mais amplo conjunto de medidas de protecção que fomentassem a entrada, permanência e saída da vítima em torno de elevados níveis de segurança, reserva e bem-estar, convocando-se assim o uso das medidas presentes no âmbito do regime de protecção de testemunhas em vigor ${ }^{48}$. Paradoxalmente, vive-se tem-

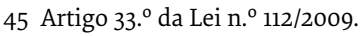

46 Artigo $32 .^{\circ}$ da Lei $.^{\circ} 112 / 2009$.

47 QuAResma, Carina - «Violência Doméstica: As expetativas das vítimas e o papel das forças de segurança». In: Politeia, Ano IX - Edição Especial, Lisboa: ISCPSI, 2014, p. 45.

48 A Lei n. ${ }^{\circ}$ 93/99, publicada em Diário da República, $1 .^{\text {a }}$ série-A - N. ${ }^{\circ} 162$ - 14 de Julho de 1999, veio regular "a aplicação de medidas para protecção de testemunhas em processo penal". Posteriormente, o diploma foi sujeito a duas alterações legais. A primeira imposta pela Lei n. ${ }^{\circ}$ 29/2008 (publicada em Diário da República, $1 .^{a}$ série N. ${ }^{\circ} 128-4$ de Julho de 2008) e a segunda introduzida pela Lei n. ${ }^{\circ} 42 / 2010$ (publicada em Diário da República, $1 .^{\mathrm{a}}$ série - N. ${ }^{\circ} 172-3$ de Setembro de 2010 ). 
pos em que são mais notórias as providências de protecção dirigidas, em Portugal, aos grupos organizados de adeptos à entrada e saída de um estádio de futebol do que às vítimas de violência doméstica no percurso até à domvs ivstitice.

$\mathrm{Na}$ área da tutela social começa-se por salientar, pela relevância do seu desígnio e por constituir uma resposta que ainda continua a escapar ao conhecimento comum do cidadão, a criação de uma rede nacional de casas de abrigo ${ }^{49}$.

Segundo, a isenção de taxas moderadoras foi aprovada para evitar qualquer entrave económico à vítima na obtenção dos necessários cuidados de saúde, assim como na recolha de prova tão crucial para a sustentação ab initio da denúncia e, a posteriori, da acusação e da fundamentação subjacente à decisão de condenação ${ }^{50}$.

Terceiro, a prioridade no acesso às ofertas de emprego ou programas de formação, sob a gestão do Instituto de Emprego e Formação Profissional, constituiu um modo de acelerar a obtenção de autonomia financeira da vítima ${ }^{51}$.

Por fim, a justificação das faltas, com remuneração integral garantida durante 30 dias ${ }^{52}$, consubstancia um suporte económico para a vítima, ao mesmo tempo que lhe confere protecção pois é altamente expectável que o agressor tente localizar o paradeiro daquela junto da sua entidade patronal.

49 O Decreto Regulamentar n. ${ }^{\circ}$ 2/2018 (publicado em Diário da República, $1 .^{a}$ série - N. ${ }^{\circ} 17$ - 24 de Janeiro de 2018) veio regular "as condições de organização e funcionamento das estruturas de atendimento, das respostas de acolhimento de emergência e das casas abrigo que integram a rede nacional de apoio às vitimas de violência doméstica, prevista na Lei n. ${ }^{\circ} 112 / 2009$. Aquele diploma foi sujeito a uma correcção de natureza meramente nominal imposta pela Declaração de Retificação n. ${ }^{\circ} 11 / 2018$, publicada em Diário da República, $1 .^{a}$ série - N. ${ }^{\circ} 57$ - 21 de março de 2018.

50 Artigo 50..$^{\circ}$ da Lei n. ${ }^{\circ}$ 112/2009. Neste sentido, o Despacho n. ${ }^{\circ}$ 20509/2008 (publicado em Diário da República $2 .^{a}$ série - N. ${ }^{\circ} 150$ - 5 de Agosto de 2008) veio determinar o regime de isenção das taxas moderadoras às vítimas de violência doméstica.

51 Artigo $48 .^{\circ}$ da Lei n. ${ }^{\circ}$ 112/2009. Nesta esteira apontam-se duas medidas concretas: em concretização do DecretoLei n. ${ }^{\circ} 132 / 99$ (publicado em Diário da República, $1 .^{a}$ série-A - N. ${ }^{\circ} 93$ - 21 de Abril de 1999) que "estabelece os princípios gerais de enquadramento da política de emprego", foi aprovada a Portaria n. ${ }^{\circ}$ 20-A/2014 (publicada em Diário da República, $1 .^{a}$ série, $1 .^{\circ}$ Suplemento - N. ${ }^{\circ} 21$ - 30 de Janeiro de 2014 , procedendo à segunda alteração à Portaria n. ${ }^{\circ}$ 204-B/2013, de 18 de Junho, que criou "a medida Estágios Emprego") que determina "a comparticipação financeira do Instituto do Emprego e da Formação Profissional, I.P., nas despesas com a bolsa de estágio, subsídio de alimentação e despesas ou subsídio de transporte visando abranger as vítimas de violência doméstica como destinatárias da medida; em realização do Decreto-Lei n. ${ }^{\circ}$ 220/2006 (publicado em Diário da República, $1 .^{\text {a }}$ série - N. ${ }^{\circ} 212-3$ de Novembro de 2006) que "estabelece o regime jurídico de protecção social da eventualidade de desemprego dos trabalhadores por conta de outrem...", foi aprovada a Portaria n. ${ }^{\circ}$ 20-B/2014 (publicada em Diário da República, $1 .^{\mathrm{a}}$ série, $1 .^{\circ}$ Suplemento - N..$^{\circ} 21$ - 30 de Janeiro de 2014) para proceder à integração de vítimas de violência doméstica nos "Contrato emprego-inserção" e "Contrato emprego-inserção+".

52 Artigo $43 .{ }^{\circ}$ da Lei n. ${ }^{0}$ 112/2009. AAVV - Violência Doméstica - implicações sociológicas, psicológicas e jurídicas do fenómeno - Manual Pluridisciplinar, Paulo Guerra e Lucília Gago (Coord.), Centro de Estudos Judiciários, Lisboa, 2016, página 339-348 (consultada a 01/05/2020). Disponível em: http://www.cej.mj.pt/cej/recursos/ebooks/outros/ Violencia-Domestica-CEJ_po2_rev2c-EBOOK_ver_final.pdf. 
Chegado a este ponto conclui-se que o referido regime jurídico consubstancia, de facto, um progresso normativo na tutela da vítima de violência doméstica, porém já evoluiu para corrigir imperfeições e adaptar-se ao tecido social ${ }^{53}$. Tanto assim é que, por exemplo, a Lei n. ${ }^{\circ}$ 129/2015, de 03/0954 derrogou o encontro restaurativo ou a mediação penal em casos de violência doméstica. E a Lei n. ${ }^{\circ}$ 24/2017, de 24/0555, compeliu o Ministério Público da jurisdição criminal a comunicar a aplicação de medidas de coacção que impeçam os contactos entre os progenitores ao seu homólogo da jurisdição de família e menores, de modo a ser urgentemente instaurado o "respetivo processo de regulação ou alteração da regulação do exercício das responsabilidades parentais“" ${ }_{56}$.

Em simultâneo foi aprovado outro regime jurídico em tutela da vítima de violência doméstica marcado, essencialmente, pelo procedimento de "concessão de indemnização" pro bono da vítima. A tramitação encontra-se a cargo de uma comissão específica, decorre num registo de celeridade e assenta numa lógica de adiantamento monetário a favor da vítima por parte do Estado, ficando reservado a este ente a possibilidade de sub-rogar-se nos direitos da pessoa lesada ${ }^{58}$.

O exercício dos direitos por parte da vítima de violência doméstica não dispensa, até pelo emaranhado de regimes jurídicos que visam a sua tutela, a consulta de um profissional e, neste sentido, o legislador acautelou que fosse assegurada à vítima uma consulta com prontidão por um advogado ${ }^{59}$. Seguindo a mesma linha de celeridade, a concessão de apoio judiciário tem um carácter urgente e da praxis decorre a impressão (dada a ausência de

53 A Lei n. ${ }^{\circ} 112 / 2009$ foi objecto, por ordem cronológica crescente, das seguintes alterações:

- Lei n. ${ }^{\circ}$ 19/2013, publicada em Diário da República, 1. ${ }^{a}$ série - N. ${ }^{\circ} 37$ - 21 de Fevereiro de 2013;

- Retificação n. ${ }^{\circ}$ 15/2013, publicada em Diário da República, 1. ${ }^{\text {a }}$ série - N. ${ }^{\circ} 55$ - 19 de Março de 2013;

- Lei n. ${ }^{\circ} 82-\mathrm{B} / 2014$, publicada em Diário da República, 1 a $^{\mathrm{a}}$ série, 1 . $^{0}$ Suplemento - N. ${ }^{\circ} 252$ - 31 de Dezembro de 2014;

- Lei n. ${ }^{\circ}$ 129/2015, publicada em Diário da República, $1 .^{a}$ série - N. ${ }^{\circ} 172$ - 3 de Setembro de 2015;

- Lei n. ${ }^{\circ}$ 42/2016, publicada em Diário da República, $1 .^{a}$ série - N. ${ }^{\circ} 248$ - 28 de Dezembro de 2016;

- Lei n. ${ }^{\circ}$ 24/2017, publicada em Diário da República, $1 .^{a}$ série - N. ${ }^{\circ} 100$ - 24 de Maio de 2017.

54 Conferir nota de rodapé n. ${ }^{\circ} 53$.

55 Conferir nota de rodapé $n . .^{\circ} 53$.

56 Artigo $31 .^{\circ}$, n. $^{\circ} 4$ da Lei n. ${ }^{\circ} 112 / 2009$, na redacção imposta pela Lei n. ${ }^{\circ}$ 24/2017.

57 A Lei n. ${ }^{\circ}$ 104/2009, publicada em Diário da República, $1 .^{\text {a }}$ Série - N. ${ }^{\circ} 178$ - de 14 de Setembro de 2009, aprovou o "regime de concessão de indemnização às vítimas de crimes violentos e de violência doméstica. Em seguimento desta lei foi aprovado o Decreto-Lei n. ${ }^{\circ}$ 120/2010, publicado em Diário da República,.$^{\text {a }}$ Série - N. ${ }^{\circ} 209$ - de 27 de Outubro de 2010, que "regula a constituição e o funcionamento da Comissão de Proteção às Vítimas de Crimes". Por sua vez, a Portaria n. ${ }^{\circ}$ 403/2012, de 7 de dezembro, publicada em Diário da República, 1. ${ }^{\text {a Série - }}$ N. ${ }^{\circ} 237$ - de 7 de Dezembro de 2012, aprovou "os modelos de requerimento para a concessão do adiantamento da indemnização por parte do Estado pelas vítimas de crimes violentos e de violência doméstica".

58 Artigo $15 .^{\circ}$ da Lei n. ${ }^{\circ}$ 104/2009.

59 Artigo $25 .^{\circ}$, n. ${ }^{\circ} 1$ da Lei n. ${ }^{\circ} 112 / 2009$

Artigos $14 .^{\circ}$ e $15 .^{\circ}$ da Lei n. ${ }^{\circ}$ 34/2004 (publicada em Diário da República, $1 .^{\text {a }}$ Série-A - N. ${ }^{\circ} 177$ - de 29 de Julho de 2004), na redação dada pela Lei n. ${ }^{\circ}$ 47/2007 (publicada em Diário da República, $1 .^{\text {a }}$ Série - N. ${ }^{\circ} 165$ - de 28 de agosto de 2007), que define o regime de acesso ao direito e aos tribunais. 
estatísticas) do deferimento ser ágil e em prazo inferior a 30 dias, ressalvando-se que ainda há situações em que o imbróglio burocrático prevalece. E recentemente foi introduzido, mediante a aprovação do Orçamento de Estado para 2020, a presunção que a vítima de violência doméstica se encontra em situação insuficiência económica até prova em contrário por forma a que a concessão do referido apoio seja efectivamente expedita ${ }^{60}$.

O legislador estabeleceu, ainda, a possibilidade do mesmo advogado acompanhar a vítima nos diferentes processos conexos com a situação de violência doméstica ${ }^{61}$. Contudo, ossos do ofício revelam que são raros os casos em que se verifica essa espécie de nomeação múltipla, qui sapit por razões afectas à burocratização dos procedimentos interinstitucionais (que se estabelecem, essencialmente, entre Segurança Social, Ordem Advogados, Tribunais e Instituto de Gestão Financeira e Equipamentos da Justiça). Deste modo, crê-se que uma imposição, por via legal, da obrigatoriedade do patrocínio multiprocessual teria sido um regime mais favorável à vítima.

A vítima de violência doméstica conta, ainda, com o apoio informativo exercido sobretudo pelas ONG's, destacando-se o serviço de atendimento telefónico permanente assegurado pela Associação Portuguesa de Apoio à Vítima (APAV) ${ }^{62}$.

Percorrer os dois principais regimes jurídicos vocacionados especificamente para a tutela da vítima de violência doméstica teve como propósito evidenciar os mecanismos e direitos mais relevantes que lhe assistem, porém serve para atestar que a dimensão normativa subjacente a esta temática não se cinge à mera criminalização da conduta prevista no

Artigo $1 .^{\circ}$, n. ${ }^{\circ}$, da Portaria n. ${ }^{\circ}$ 10/2008, publicada em Diário da República, $1 .^{a}$ Série - N. ${ }^{\circ} 2$ - de 3 de Janeiro de 2008 , que regulamenta o regime de acesso ao direito e aos tribunais.

60 A Lei n. ${ }^{\circ}$ 2/2020, publicada em Diário da República, $1^{\text {a }}$ série - N. ${ }^{\circ} 64$ - 31 de Março de 2020, aprova o Orçamento do Estado para 2020 e provoca através dos artigos 389..$^{\circ}$ e 390. ${ }^{\circ}$, respectivamente, um aditamento à Lei n. $.^{\circ} 34 / 2004$ e uma alteração à Lei n. $.^{\circ} 112 / 2009$ nos seguintes termos:

Lei $.^{\circ} 34 / 2004$

Artigo 8. ${ }^{\circ}-\mathrm{C}$

Vítimas de violência doméstica

1 - No caso de atribuição do estatuto de vítima do crime de violência doméstica previsto no artigo $152 .^{\circ}$ do Código Penal, nos termos da Lei $n^{\circ}{ }^{0} 112 / 2009$, de 16 de setembro, presume-se, até prova em contrário, que a vítima se encontra em situação de insuficiência económica.

2 - Nos casos previstos no número anterior, é garantida à vítima a célere e sequente concessão de apoio judiciário, com natureza urgente.

Lei $.^{\circ}{ }^{0} 112 / 2009$

Artigo $25^{\circ}$

[...] 1 - É garantida à vítima, com prontidão, consulta jurídica a efetuar por advogado, bem como a célere e sequente concessão de apoio judiciário, com natureza urgente, nos termos legais. [...]

61 Artigo $25 .^{\circ}$, n. ${ }^{\circ} 2$, da Lei n. ${ }^{\circ} 112 / 2009$.

62 O Protocolo n. ${ }^{\circ}$ 17/200o, publicado em Diário da República, $2 .^{a}$ série - N. ${ }^{\circ} 118$ - 22 de Maio de 2000 - foi celebrado entre o Ministro da Justiça, a Ministra para a Igualdade e a Associação Portuguesa de Apoio à Vítima (APAV) com o desígnio de consagrar o serviço de atendimento telefónico permanente às vítimas de violência doméstica. Consultar, em particular, a cláusula $2 .^{\mathrm{a}}$, alínea b). 
artigo $152 .{ }^{\circ}$ do CP. Com isto se pretende afirmar que a especialização na área da VD vai mais além do aludido conhecimento penal, sendo este apenas uma parte de um todo e é crucial para o apoio profissional à vítima ser assertivo que o conhecimento do técnico seja o mais denso e assente numa fluente articulação entre os diferentes instrumentos normativos.

Acresce que o contexto de violência doméstica que envolve a vítima é tão singular que pode impor a necessidade de também ser apoiada na resolução - múltipla e em simultâneo - de conflitos que implicam um enquadramento normativo mais vasto do antes retratado. Provando com exemplos, a vítima de violência doméstica pode ser parte activa ou passiva - para além do processo-crime - em processos (ora de natureza cautelar, ora definitiva) de divórcio, de prestação de alimentos, de regulação das responsabilidades parentais ou de promoção e protecção de menores (quando estes estejam sob a sua responsabilidade), de partilha patrimonial, de insolvência pessoal, de execução de dívidas, de despedimento laboral, de despejo habitacional, et caetera.

Em remate, a tutela da vítima de violência doméstica implica um apoio técnico pluridisciplinar que, também, se reflecte na dimensão jurídica dado que pode carecer de patrocínio em diversos processos, que cobrem diferentes áreas do direito para a qual o mesmo advogado pode consubstanciar uma mais valia. Ademais, urge a presença obrigatória do advogado, particularmente no âmbito penal e de família e menores, desde a fase processual preliminar.

\section{Apoio técnico-jurídico prestado à vítima de violência doméstica}

O apoio técnico conferido à vítima de violência doméstica desdobra-se, consoante os casos, em diferentes valências profissionais. Entre estas têm assumido maior protagonismo as funções prestadas pelo polícia, médico (especialmente, o psicólogo), advogado e assistente social, sem menosprezo pelas demais que avocam para si igual distinção, consoante as necessidades que a vítima pretende colmatar.

Soma-se à multidisciplinaridade a complementaridade profissional. Somente um apoio integrado (ou em rede) e sincronizado pode conduzir a vítima a obter maior estabilidade e confiança, sendo estas atributos essenciais para o afastamento daquela do contexto marcado pela violência doméstica.

Prova concreta deste aspecto extrai-se da situação em que a vítima recusa peremptoriamente apresentar queixa contra o agressor. Esta posição assumida configura um momento crítico ou, mesmo, decisivo, para a assertividade da intervenção dos profissionais que a rodeiam.

Neste âmbito, é importante que o profissional reconheça, após tomar conhecimento do crime practicado e da intenção vítima não apresentar queixa, o dever de denunciar a situa- 
ção às autoridades competentes, dado tratar-se de um crime de natureza pública ${ }^{63}$. É seguro afirmar que ao jurista ou ao advogado é confortável, por hábito, medir as implicações que envolvem a apresentação, ou não, de uma queixa-crime. Porém, igual dever germina para os demais profissionais que naquele contexto contactem com a vítima.

Posto isto e ainda que exista o referido ónus de denúncia, tem sido praxis nos serviços especializados de apoio às vítimas de violência doméstica efetuar-se uma espécie de gestão do momento adequado para a denúncia sem desrespeito pelo prazo de seis meses, ao fim do qual extingue-se o direito à queixa ${ }^{64}$. Para o efeito, tem sido considerado capital que a denúncia ocorra somente após o momento em que já se tenha implementado uma estratégia de protecção da vítima, dado que a natureza pública do crime promove o "accionamento de várias medidas de protecção" ${ }^{\text {. }}$. Com tal conduta pretende-se evitar que o conhecimento da queixa por parte do autor do crime coloque a vítima numa situação de maior perigo do que a vivida antes da respectiva participação.

Em particular, o advogado deve neste cenário assumir um papel igualmente proactivo, sem descurar a reserva da factualidade encoberta pelo segredo profissional ${ }^{66}$, razão pela qual se pensa que o levantamento do sigilo deve merecer um tratamento processual ágil (dispensando-se procedimentos excessivamente burocráticos) em prol da tutela da vítima de violência doméstica.

Aprofundando o apoio técnico-jurídico prestado à vítima de violência doméstica, almeja-se destrinçar três tipos de profissionais: o técnico de apoio à vítima (comummente apelidado pela sigla TAV), o jurista e o advogado.

O TAV é, em termos legais, "a pessoa devidamente habilitada que, no âmbito das suas funções, presta assistência direta às vítimas"67. Os pressupostos e o procedimento a cumprir na aspiração a $\mathrm{TAV}^{68}$, controlados actualmente pela Comissão para a Cidadania e Igualdade de Género ${ }^{69}$, implicam que o candidato seja, por um lado, portador de uma habilitação

63 A natureza pública do crime de violência doméstica decorre da alteração provocada ao CP pela Lei n. ${ }^{\circ}$ 59/2007 e é uma expressão de protecção máxima da dignidade da pessoa humana (artigo $1 .^{\circ}$ da CRP).

64 Artigo $115 .^{\circ}$, n. ${ }^{\circ}$ 1, do Código Penal.

65 Alves, Flávio Santos - «Resposta Organizacionais da PSP em Relação ao Crime de Violência Doméstica». In: Politeia, Ano IX - Edição Especial, Lisboa: ISCPSI, 2012, p. 79.

66 Artigo 92. ${ }^{\circ}$, n. ${ }^{\circ}$ 1, do EOA estatui que: "o advogado pode revelar factos abrangidos pelo segredo profissional, desde que tal seja absolutamente necessário para a defesa da dignidade, direitos e interesses legítimos do próprio advogado ou do cliente ou seus representantes, mediante prévia autorização do presidente do conselho regional respetivo, com recurso para o bastonário, nos termos previstos no respetivo regulamento."

67 Artigo $2 .^{\circ}$, alínea c), da Lei n. ${ }^{\circ} 112 / 2009$.

68 Artigo $83 .^{\circ}$, n. ${ }^{\circ}$, da Lei n. ${ }^{\circ} 112 / 2009$.

69 Alínea a), do Ponto 1-, do Despacho n. ${ }^{\circ}$ 6810-A/2010, publicado em Diário da República, 2..$^{a}$ série, $1 .^{\circ}$ Suplemento - N. 74 - 16 de Abril de 2010, que "define os requisitos e qualificações necessários à habilitação dos técnicos de apoio à vítima". No que respeita ao nível da habilitação, o Ponto 4- do mesmo diploma contemplou a seguinte excepção: "as pessoas que, à data da entrada em vigor do presente despacho, sejam detentoras de habilitação 
académica de nível superior, preferencialmente na área das ciências sociais e humanas ou, em alternativa a esta, deter experiência profissional relevante no domínio da violência doméstica. E, por outro, o candidato deve obter aprovação numa formação teórico-práctica, com a duração de 90 horas $^{70}$.

Cruzando essa função com os recursos humanos admitidos em casas de abrigo, descortina-se que esta resposta social dá preferência à contratação de $\mathrm{TAV}^{71}$. E adensa a mesma quanto às habilitações, dando prevalência às áreas de serviço social, psicologia, educação social e direito ${ }^{72}$.

O jurista ou jurisconsulto é um profissional habilitado, após a conclusão da formação superior em direito, a proferir pareceres sobre questões de índole jurídica. Em contexto de violência doméstica, destaca-se o papel de informar a vítima sobre os seus direitos e deveres. Porém, esta função informativa não se deve equiparar à consulta jurídica que está reservada ao advogado, como mais adiante se irá dar conta com detalhe, ressalvando-se a situação especial dos "juristas de reconhecido mérito" e dos "mestres ou doutores em Direito"73.

O jurista pode prestar o referido apoio de modo individual ou institucional, sendo que nesta última dimensão ressalta, logo, de exemplo a sua intervenção no âmbito da casa de abrigo.

O advogado, considerado comummente como jurista particularmente qualificado, é o profissional a quem está exclusivamente reservada a práctica dos denominados "actos próprios dos advogados"74. Destacam-se destes "o exercício do mandato forense", "a consulta jurídica"75 e "todos aqueles que resultem do exercício do direito dos cidadãos a fazer-se acompanhar por advogado perante qualquer autoridade"76.

A consulta jurídica reservada ao advogado ${ }^{77}$ é uma actividade que funde os elementos de interpretação das normas e respectiva aplicação em tese, tal como o jurista está apto a exe-

de nível secundário e exerçam, comprovadamente, a função de técnico de apoio à vítima ficam dispensadas do cumprimento do requisito da posse de habilitação de nível superior previsto na alínea a) do n. ${ }^{\circ}$ 1."

70 Alínea b), do Ponto 1-, do Despacho n. ${ }^{0}$ 6810-A/2010.

71 Artigo $44 .^{\circ}$, n. ${ }^{\circ} 1$, do Decreto Regulamentar n. ${ }^{\circ} 2 / 2018$.

72 Artigo $44 .^{\circ}{ }^{\text {n }} .^{\circ}$ 2, do Decreto Regulamentar n. ${ }^{\circ}$ 2/2018.

73 Artigo $1 .{ }^{\circ}$, n. ${ }^{\circ}$ 2, da Lei n. ${ }^{\circ}$ 49/2004 (publicada em Diário da República,.$^{\text {a }}$ série-A - N. $^{\circ} 199$ - 24 de Agosto de 2004) e artigo $200{ }^{\circ}$, da Lei n. ${ }^{\circ}$ 145/2015 (publicado em Diário da República, $1 .^{a}$ série - N. ${ }^{0} 176$ - 9 de Setembro de 2015), usualmente referida por Estatuto da Ordem dos Advogados (EOA).

74 Artigo $1 .^{\circ}$, da Lei n. ${ }^{\circ}$ 49/2004 e artigo $66 .^{\circ}$, n. $^{\circ}{ }^{1}$, do EOA.

75 Artigo $1 .^{\circ}$, n. ${ }^{\circ}$, da Lei n. ${ }^{\circ} 49 / 2004$.

76 Artigo $1 .^{\circ}$, n. ${ }^{\circ}$ 9, da Lei n. ${ }^{\circ}$ 49/2004.

77 Em modo de excepção, o advogado estagiário pode prestar consulta jurídica desde que esteja sob a orientação do respectivo patrono - artigo $196 .^{\circ}, \mathrm{n} .^{\circ} 1$, alínea b), e n. ${ }^{\circ} 2$ do EOA. 
cutar, com o de aconselhamento do modo como, a partir da casuística apresentada, devem ser exercidos os direitos e satisfeitas as pretensões que legalmente assistem ao cliente ${ }^{78}$.

O referido aconselhamento pressupõe, em regra, uma remuneração ${ }^{79}$ e é desencadeado por uma solicitação, como reza a lei, "de terceiro", no qual se inclui obviamente a vítima. Por fim, o advogado pode conceder a consulta ora no âmbito do acesso ao direito, como dever-desígnio diante da comunidade ${ }^{80}$, ora em modo individual ou liberal, sendo certo que em ambos o exercício da advocacia comunga exactamente dos mesmos princípios deontológicos.

A consulta jurídica pode representar a antecâmara, ou não, do mandato forense que venha a ser atribuído pela vítima ao advogado. Estando este devidamente mandatado pode, destaca-se, exercê-lo diante de qualquer tribunal - mandato judicial - e actuar em representação do mandante para negociar a constituição, alteração ou extinção de relações jurídicas - mandato com representação ${ }^{81}$. Esta representação adquire, no âmbito da violência doméstica, limitações e a melhor prova da indisponibilidade dos direitos da vítima é a suspensão provisória do processo-crime depender da sua livre e esclarecida vontade ${ }^{82}$.

O mandato forense inicia-se por livre escolha do cliente ou por nomeação atribuída pela entidade legalmente competente ${ }^{83}$. A execução do mandato pauta-se pelo equilíbrio entre, por um lado, a liberdade, independência, isenção e plena autonomia técnica do advogado ${ }^{84}$, e, por outro, a responsabilidade daquele prosseguir interesses estritamente profissionais que visem defender os direitos, liberdades e garantias fundamentais do cliente, ao mesmo tempo que pugna pela aplicação célere e mais adequada das normas (legais e deontológi(as) $)^{85}$.

Para finalizar, o TAV não tem de ser, necessariamente, expertise em direito, embora possa ser jurista e não há impedimento legal para, simultaneamente, ser advogado da vítima. $\mathrm{O}$ jurista pode aspirar a ser TAV e cumular funções com a advocacia. O advogado é o único

78 Artigo $3 .^{\circ}$ da Lei n. ${ }^{\circ}$ 49/2004 e artigo $68 .^{\circ}$ do EOA.

79 A consulta jurídica prestada no âmbito do acesso ao direito confere ao advogado uma retribuição de $1 / 4$ UC (Unidade de Conta), que corresponde à módica quantia de $25,50 €-\operatorname{artigos~} 6 .^{\circ}, \mathrm{n} .{ }^{\circ} 1,14 .^{\circ}$ e $15 .^{\circ}$ da Lei n. ${ }^{\circ} 34 / 2004$, e Ponto 11-, do Anexo da Portaria n. ${ }^{0} 1386 / 2004$ (publicada em Diário da República, 1. ${ }^{\text {a }}$ série-B - N. ${ }^{0} 264-10$ de Novembro de 2004) por força do artigo $25 .^{\circ}$, n. ${ }^{\circ}$ 1, da Portaria n. ${ }^{\circ}$ 10/2008 (publicada em Diário da República, $1 .^{\mathrm{a}}$ série - N. ${ }^{\circ} 2-3$ de Janeiro de 2008). E fora daquele âmbito é, igualmente, saldada em dinheiro e esta quantia deve obedecer à "compensação económica adequada pelos serviços prestados" - $\operatorname{artigo~} 105 .{ }^{\circ}, \mathrm{n} .{ }^{\circ} 1$ do EOA -, salvo se o advogado actuar a título do comummente designado pro bono.

80 Artigo $90 .{ }^{\circ}$, n. $^{\circ}$ 2, alínea f), do EOA e artigo $20 .^{\circ}$, n. $^{\circ} 1$ e n. ${ }^{\circ} 2$ da CRP.

81 Artigo $67 . .^{\circ}$, n. ${ }^{\circ}$, alíneas a) e b) do EOA e artigo $2 .^{\circ}$, da Lei n. ${ }^{\circ}$ 49/2004.

82 Artigo $281 .^{\circ}, \mathrm{n} .{ }^{\circ} 7$, do Código de Processo Penal.

83 Artigo $98 .^{\circ}$, n. ${ }^{\circ}$ 1, do EOA.

84 Artigo $81 .^{\circ},{ }^{\circ}{ }^{\circ} 1$, e artigo $97 .^{\circ}$, n..$^{\circ}$ 2, do EOA.

85 Artigo $90 .{ }^{\circ}$, n. $^{\circ} 1$ e n. ${ }^{\circ} 2$ alínea $g$ ), do EOA. 
profissional que pode prestar consulta jurídica à vítima e representá-la em juízo, porém não está impedido de habilitar-se a ser TAV e exercer funções de jurista.

\section{A especialização do advogado em violência doméstica}

A par da probidade, rectidão e honestidade ${ }^{86}$, a especialização do advogado é um factor de interesse para o cliente dado que representa um estímulo à sua confiança ${ }^{87}$ saber que, ao solicitar os serviços de advocacia, pode estar diante de um profissional que apresente, ou não, credenciais diferenciadas por domínio acrescido da área do direito em que vai operar.

Por princípio, está vedado ao advogado invocar uma área que considere ser a sua especialidade, particularmente por meios publicitários. Para divulgar a sua qualidade especial carece de autorização da Ordem dos Advogados ${ }^{88}$.

O Estatuto da Ordem dos Advogados vigente expressa, desde 2015, diversas áreas em que o advogado pode identificar-se como especialista ${ }^{89}$, as quais se crê subdividirem-se entre as designadas áreas clássicas - tais como, o Direito Constitucional, Administrativo, Fiscal, Financeiro e do Trabalho - e áreas contemporâneas - Direito Europeu e da Concorrência9 ${ }^{90}$.

A posteriori foi aprovado o "Regulamento Geral das Especialidades", provocando uma evolução no sentido de consagrar as áreas já reconhecidas - Direito Constitucional, Administrativo, Fiscal e do Trabalho -, de ampliar e, assim, prever novas especialidades - Direito da Família e Menores, do Consumo, do Ambiente, da Igualdade de Género, da Saúde e Bioética, Criminal e Societário - e de ajustar algumas áreas consagradas à realidade presente Direito da Propriedade Intelectual, Industrial e da Concorrência, e Direito Europeu (sendo

86 Ponto 2. das notas do artigo 97. ${ }^{\circ}$ do EOA in Magalhães, Fernando Sousa - Estatuto da Ordem dos Advogados Anotado,

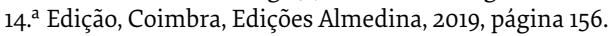

87 Artigo $97 .^{\circ}$, n. $^{\circ}$ 1, do EOA.

88 Artigo $70 .{ }^{\circ}$, n. $^{\circ} 3$, e artigo $94 .^{\circ}$, n. $^{\circ} 2$, alínea $f$ ), do EOA.

89 O EOA vigente veio tornar expressa a especialização do advogado no seu artigo $70 .^{\circ}$, ao invés do EOA precedente

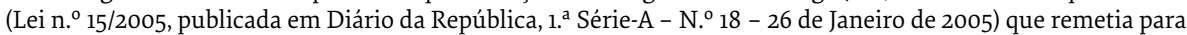
regulamento autónomo essa abordagem. Encontra-se no Regulamento n. ${ }^{\circ}$ 204/2006 (publicado em Diário da República, 2..$^{\text {a }}$ série - N. ${ }^{\circ} 209$ - 30 de Outubro de 2006) o regime de atribuição do título de advogado especialista

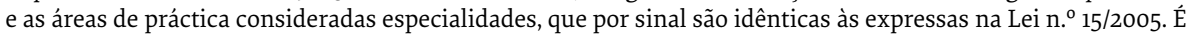
necessário recuar ao Regulamento n. ${ }^{\circ} 15 / 2004$ (publicado em Diário da República, 2..$^{a}$ série - N. ${ }^{\circ} 81-5$ de Abril de 2004) para encontrar uma lista de especialidades mais resumida composta pelas seguintes áreas: Direito administrativo; Direito fiscal; Direito do trabalho.

90 Artigo $70 .^{\circ}$, n. $^{\circ}$, do EOA. 
que esta última área foi autonomizada da anterior) ${ }^{91}$. Neste domínio, a mais recente alteração determinou o reconhecimento da especialidade de Direito Marítimo ${ }^{92}$.

Releva, agora, prender-se com detalhe ao referido regulamento para apreciar os moldes de atribuição do título de "especialista". Este impõe, essencialmente, que o advogado exerça há pelo menos dez anos e de modo ininterrupto na área de que pretende arrogar essa qualidade. Além disso, o advogado deve demonstrar competência teórico-práctica na especialidade a que se candidata, sendo necessário para o efeito advogar e acumular formação93.

A obtenção do título de advogado especialista assenta num procedimento exigente pois, além do dever de comprovar documentalmente a sua formação e práctica na área jurídica a que se propõe ${ }^{94}$, que pode ser complementada com declarações abonatórias de terceiros ${ }^{95}$, o advogado é sujeito a uma prova oral pública para esclarecer o seu currículo profissional e demonstrar domínio da respectiva especialidade ${ }^{96}$.

Após a atribuição do título de especialista, o advogado deve apresentar, ao fim de 5 anos, um "curriculum profissional" que dê mostras de ter acumulado experiência profissional e formação teórica na mesma área, sob pena de caducar automaticamente ${ }^{97}$.

Posto isto, afirmar que um advogado seja especialista em violência doméstica não tem sustento normativo (ora estatutário, ora regulamentar). Ainda que o cliente possa questionar ao advogado pelo grau de domínio em assuntos afectos à violência doméstica, é seu dever esclarecer que a Ordem dos Advogados não reconhece aquela especialidade. No entanto, o advogado não está impedido de expor ao seu cliente que tem acumulado práctica forense, sobretudo judicial, na tutela das vítimas de violência doméstica, ao mesmo tempo que tem acolhido formação teórica na área (como é exemplo notório o curso TAV).

De todo o modo, importa equacionar, em tese, a viabilidade do advogado requerer à respectiva Ordem que seja reconhecido a qualidade de especialista em violência doméstica pelo acumular, há mais de dez anos, de experiência teórico-práctica nesse âmbito.

Antevê-se, desde logo, o indeferimento liminar dessa pretensão como reacção preliminar e imediata do Conselho Geral da Ordem dos Advogados, caso o candidato invoque especificamente a especialidade em "violência doméstica", a qual não é legalmente reconhecida consoante já foi frisado ${ }^{98}$.

91 Artigo $5 .^{\circ}$ e Anexo do Regulamento n. ${ }^{\circ}$ 9/2016 (publicado em Diário da República, $2 .^{a}$ série - N. ${ }^{\circ} 3-6$ de Janeiro de 2016).

92 Deliberação n. ${ }^{\circ}$ 1004/2016 (publicado em Diário da República, 2. ${ }^{\text {a }}$ série - N. ${ }^{0} 116$ - 20 de Junho de 2016).

93 Artigo $3 .^{\circ}$ e $4 .^{\circ}, \mathrm{n} .^{\circ} 1$, do "Regulamento Geral das Especialidades" (RGE).

94 Artigo $6 .^{\circ}$, n. ${ }^{\circ} 2$ e n. ${ }^{\circ} 3$, e artigo $7 .^{\circ}$ do RGE.

95 Artigo $6 .^{\circ}, \mathrm{n} .^{\circ} 4$, do RGE.

96 Artigo $10 .^{\circ}, \mathrm{n} .^{\circ} 2$, do RGE.

97 Artigo $4 .^{\circ}$, n. ${ }^{\circ}$ 2, do RGE.

98 Artigo $6 .^{\circ}$, n. ${ }^{\circ} 3$, do RRGE. 
Avançando na equação explora-se, agora, em que medida a experiência acumulada no âmbito da violência doméstica pode constituir fundamento para o advogado ser considerado especialista numa área efectivamente reconhecida, testando-se - por razões óbvias - o "Direito Criminal", o "Direito da Família e Menores" e o "Direito da Igualdade de Género".

Seguindo a linha de pensamento anteriormente explanada, não restam dúvidas que a violência doméstica emergiu no nosso ordenamento pelo Direito Criminal, com a introdução do tipo legal de crime que visa reprimir aquela conduta. Porém, a violência doméstica é um flagelo social que não se resume ao foro criminal até porque a recusa da vítima na denúncia do crime (e este configura um cenário mais real do que hipotético) exclui a intervenção penal, ainda que não elimine a qualidade de pessoa ofendida. Acresce que a tutela da vítima implica, consoante os casos, o recurso judicial por áreas do direito distintas da penal, sobressaindo-se o domínio da família e de menores.

A mesma linha de raciocínio desenvolvida serve para vetar a candidatura do advogado à especialidade em "Direito da Família e Menores". E dado que o regulamento sub judice não contempla uma candidatura conjunta a diferentes especialidades, julga-se insustentável que o advogado com experiência acumulada em violência doméstica aglomere a qualidade de especialista em "Direito Criminal" e "Direito da Família e Menores". Analisando por outro prisma, a candidatura às especialidades invocadas pode ser efectuada em simultâneo e separadamente, porém crê-se improvável o deferimento pelo Conselho Geral da Ordem dos Advogados, dado que a experiência afecta à violência doméstica funda-se exactamente na mesma experiência e curriculum.

Por fim, a especialidade advocatória em "Direito da Igualdade de Género" não se coaduna com a violência doméstica. Ainda que esta se reproduza, pelos indicadores aludidos, em larga escala no seio das relações conjugais, evidenciando a desigualdade ou o predomínio do género masculino sobre o feminino, a dimensão pessoal subjacente à violência doméstica é mais ampla, sendo a violência filio-parental um claro exemplo99.

Para concluir, conjecturam-se os obstáculos à inclusão da violência doméstica na referida lista da especialidade do advogado. Esta temática não corresponde a uma disciplina autónoma do direito, além de que a defesa da vítima pode alastrar a intervenção por diversos domínios jurídicos, sendo que determinados destes já estão reconhecidos como especialidades da advocacia (como, reitera-se, o direito criminal e, o direito de família e menores). Em sentido inverso, a admissão da especialidade "Direito da Igualdade de Género" é

99 Conferir o Acórdão do Tribunal da Relação de Guimarães, no processo n. ${ }^{\circ}$ 2255/15.7T9PRT.P1, de 12/10/2016 (consultado a 01/05/2020) Disponível em: http://www.dgsi.pt. 
um sinal claro da especialidade do advogado não ter, forçosamente, de corresponder a uma típica área do direito.

Em suma, o "Regulamento Geral das Especialidades" não contempla a especialização do advogado em violência doméstica, ainda que esse reconhecimento consubstanciasse um reforço condigno da tutela da vítima, além de ampliar a sua confiança no advogado.

\section{Considerações ad futurum}

Pensar na especialização do advogado em violência doméstica é uma cogitação focada na posição da advocacia, quer na matriz institucional a cargo da Ordem dos Advogados, quer na matriz individual exercida pelo advogado, enquanto profissão indispensável para a efectivação dos direitos, liberdades e garantias fundamentais da vítima de violência doméstica ${ }^{100}$.

Dado que a violência doméstica não é, aos dias de hoje, uma área reconhecida pela Ordem dos Advogados que conduza à atribuição de um título de especialista, tem-se de situar a apreciação do à-vontade do advogado no domínio da temática mediante duas perspectivas: o da competência e o da disponibilidade $\mathrm{e}^{101}$.

A disponibilidade é conditio sine qua non para o advogado aceitar o patrocínio. Contudo, o advogado, ainda que preveja impossibilidade ou mera restrição que o afaste da gestão imediata do assunto que lhe seja confiado, pode aceitar o patrocínio desde que actue conjuntamente com outro colega que apresenta essa disponibilidade.

Este panorama de cooperação entre advogados, cujos moldes é desnecessário neste momento verter, é uma práctica rotineira da actividade. Sucede, porém, que no âmbito da violência doméstica, a referida actuação conjunta pode comprometer o apoio mais adequado à vítima.

É consabido que a vítima procura obter suporte em determinada pessoa ou profissional, que constitua a alavanca para abandonar definitivamente a relação marcada pela violência.

O advogado pode assumir ou, até, ser um forte candidato a desempenhar esse papel, considerando a importância de deter elevados conhecimentos jurídicos. Indubitavelmente está reservado ao advogado a capacidade para informar a vítima, esclarecer os procedimentos e timings judiciais, bem como prestar as orientações que salvaguardem os interesses da mesma conduzindo-a para uma situação futura em que venha a obter segurança e paz. Desse modo, o vínculo entre o advogado e a vítima supera o patamar da confiança, a qual 
(reitera-se) ser essencial e recíproca para a harmonia da relação, e eleva-se para o grau de "referência".

São vários os indicadores que revelam as circunstâncias em que o advogado se assume diante da vítima como uma espécie de "técnico de referência".

Primeiro, a relação torna-se unidireccional e a vítima jamais toma uma decisão sem a respectiva validação pelo advogado.

Segundo, a indispensabilidade da presença do advogado na fase pré e pós-judicial para a efectiva tutela da vítima equipara-se à sua obrigatoriedade de estar em juízo ${ }^{102}$.

Terceiro, os atendimentos são, por norma e como costume da profissão ${ }^{103}$, executados de modo presencial e em sessões contínuas, com um carácter de periodicidade frequente, embora, adaptável às circunstâncias (oscilando, assim, entre o mínimo de 1 a 2 sessões semanais, até ao máximo de um contacto quinzenal).

Quarto, qualquer diligência que exija a presença da vítima diante das autoridades é cumprida sempre com o acompanhamento do advogado, ainda que a intervenção deste não seja exigida por lei ou, tenha uma dimensão e oportunidade diminuta.

Quinto, o pedido de indemnização (em dinheiro) a favor da vítima não deve resumir-se ao arbitramento oficioso ${ }^{104}$. $\mathrm{O}$ advogado deve trabalhar a motivação da vítima na formulação desse pedido quando esta manifeste a habitual recusa ou desinteresse pelo ressarcimento. Para determinar esta transformação, é imperioso dar inicialmente por assente que a compensação financeira nunca há-de representar uma digna alternativa à reconstituição natural da realidade passada. A partir deste ponto, importa consciencializar a vítima que a auto-negação do ressarcimento é abdicar de um direito que corrói o binómio "liberdade-responsabilidade" - princípio elementar e indispensável à convivência social - e, porventura, com repercussões futuras em alterações normativas que diminuam a tutela das demais vítimas. Neste âmbito, assinala-se que, em certos casos, tem obtido resultados prácticos profícuos expor-se à vítima que o modo de pagamento pode ser concretizado com base num adiantamento por parte do Estado Português ${ }^{105}$ (o que afasta a indisponibilidade

102 A fase pré-judicial é marcada, basicamente, pelo direito à informação para capacitar ou empoderar a vítima na adopção de condutas que contribuam para a erradicação da violência doméstica. Esta fase pode consubstanciar a antecâmara da fase judicial, marcada pela propositura e prosseguimento de processos judiciais. E a fase pósjudicial verifica-se após o trânsito em julgado de todos os processos e foca-se no apoio à vítima para em face da evolução das circunstâncias ser apreciado quaisquer alterações que possam justificar nova intervenção judicial.

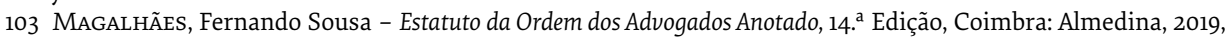
p. 96 - ponto 9. das notas do artigo $68 .^{\circ}$ do EOA.

104 Conferir nota de rodapé n. ${ }^{\circ} 57$.

105 Conferir nota de rodapé n. ${ }^{\circ} 57$ e 58 . 
financeira do efectivo responsável) e da indemnização consubstanciar um apoio extremamente útil para a autonomização da vítima, dado ser frequente a sua fragilidade financeira.

Por fim, a advocacia deve assumir-se como um meio efectivo de suporte para a vítima cambiar a violência pela paz doméstica e, quando este cenário se concretiza, a vítima vai seguramente enaltecer o resultado obtido destacando o contributo do advogado.

Posto isto, o patrocínio aceite por um advogado na condição de ser exercido por outro, que demonstre tal disponibilidade, pode constituir dois dilemas que merecem de seguida atenção.

No momento em que a indisponibilidade do advogado ocorre ab initio, a vítima pode ver gorada a confiança depositada no profissional que escolheu para o seu patrocínio. Em sequência, antevê-se que a intenção da vítima em exercer os seus direitos seja enfraquecida, além de que compromete a futura confiança no advogado recomendado. Descendo à realidade, pense-se na situação típica da vítima que vive anos a fio (para não dizer décadas) sem se libertar da relação abusiva e, quando obtém coragem para dar esse passo, pode escutar uma resposta "meio-termo".

Por sua vez, no momento em que a indisponibilidade do advogado se verifica a posteriori ou durante o decurso do processo judicial, o sentimento de insegurança e descrédito no advogado mandatado apossam-se da vítima e, em sequência, compromete-se a qualidade de intervenção judicial e, concomitantementem a diminuição das respetivas garantias. Concretizando, não é recomendável o advogado prescindir a reunião presencial com a vítima em momento prévio à intervenção judicial e tão-pouco não estabelecer contacto com aquela antes dessa diligência. Não é, de todo, recomendável que a vítima, em cumprimento de convocatória para diligência judicial, seja, somente nesse momento, confrontada com a representação por advogado, com base em substabelecimento, diferente daquele inicialmente mandatado.

No que concerne à competência, o advogado, nos mesmos moldes antes elucidados quanto à disponibilidade, pode aceitar o patrocínio desde que actue conjuntamente com outro colega que apresente essa aptidão.

A competência do advogado representa no apoio conferido à vítima de violência doméstica a outra face da moeda composta pela disponibilidade. Deste modo, as observações já apresentadas acerca da confiança e (eventual) nível de "referência" no plano da disponibilidade, consideradas essenciais para a harmonia da relação advogado-cliente/vítima, são profícuas no plano da competência do advogado, mutatis mutandis.

Sob o ponto de vista da competência, aprecia-se o conforto do profissional mediante o domínio das diversas áreas do direito (e, quiçá, de outras áreas científicas) que abarquem as necessidades de tutela da vítima de violência doméstica, cuja amplitude está intrinsecamente afecta à singularidade da casuística e à mutação frequente das circunstâncias envolventes. 
No seguimento da linha de pensamento anteriormente exposta, o campo jurídico subjacente a uma situação de violência doméstica não se cinge ao código penal (e, obviamente, ao processo penal). É indiscutível que idealiza uma óptima base de conhecimento o facto do advogado manusear assiduamente esses códigos, conjugando-os com o "regime jurídico aplicável à prevenção da violência doméstica, à protecção e à assistência das suas vítimas", sem preterir o respectivo entroncamento no direito constitucional, europeu e internacional. Porém, soma-se ao dever do advogado, este estar apto para observar e invocar as normas dos demais ramos de direito em que se enquadrem as necessidades e interesses que a vítima pretende tutelar.

O domínio e a conjugação assertiva de diversos e vastos instrumentos normativos implicam que o serviço do advogado atinja um nível de exigência considerável. Contudo, o raio de acção do advogado pode ser superior quando ambiciona absorver conhecimentos de outras áreas científicas que se debruçam sobre a mesma problemática.

Este plus gnosiológico potencia a qualidade do atendimento e orientação jurídica, dado que amplia o leque de ferramentas e saberes que permitem ao advogado compreender melhor a situação vivencial da vítima. Neste sentido, os contributos científicos mais profícuos situam-se nos domínios da psicologia, psiquiatria, criminologia, sociologia, assistência e reinserção social. Em detalhe, conteúdos associados à vitimologia, às dinâmicas da violência doméstica e, à reinserção e prevenção da revitimização dilatam o know-how do advogado que pretenda patrocinar uma vítima de violência doméstica.

A absorção de conhecimento extrajurídico pelo advogado representa um engrandecimento ad hoc à sua formação base, o qual pode ser obtido de modo informal ou programado, sendo que este último confere habitualmente uma certificação ou diploma. Com isto não se pretende induzir que a especialização do advogado em violência doméstica deve passar, forçosamente, pela frequência de formação específica nessa área (identificando-se, neste momento, o curso TAV como o melhor exemplo possível), porém essa opção aprimora sem dúvida a sua actuação.

Nesta esteira, o advogado deve assumir, também, uma postura de cooperação em rede com os demais profissionais que prestem assistência e protecção à vítima. O advogado que promova esse envolvimento em rede, amplia a segurança da vítima ao mesmo tempo que exerce um patrocínio proactivo e, consequentemente, fortalecedor da confiança essencial para a relação profissional ${ }^{106}$.

106 Por exemplo: o advogado deve informar a vítima que tem o direito de recolher os seus pertences pessoais na residência onde permaneça o agressor e ser acompanhada, quando necessário, pelas autoridades policiais; o advogado pode estabelecer contacto com a esquadra competente para aferir qual o modus operandi no acompanhamento da vítima à residência, porém uma vez efectuada essa ligação com as autoridades deve, 
Posto isto, todo o advogado deve realizar, previamente à aceitação do patrocínio de uma vítima de violência doméstica, um exercício de consciência acerca da sua disponibilidade e competência, reconhecendo que ao assumir o serviço está a comprometer-se com uma intervenção proactiva, meticulosa, dinâmica e harmoniosa com os diversos modos de apoio à vítima e apta a dar cobertura nas diferentes áreas do direito necessárias à efectivação dos direitos, liberdades e garantias fundamentais do cliente.

Ao longo do presente artigo nunca foi proferido o termo "honorários", porém neste âmbito é um tópico que não pode passar em branco. De todo o modo, o critério legal definido no EOA é extramente claro. Este oferece a consabida amplitude de fixação de honorários, mediante a qual o advogado justifica pelo serviço prestado uma compensação económica concreta, sendo que na práctica a conta apresentada ao cliente pode resumir-se a umas razoáveis centenas de euros até a uns sobejos milhões ${ }^{107}$.

A atenção rogada não deve prender-se, assim, com o critério de fixação de honorários porque a partir do momento que o advogado descrimine os serviços e apresente um valor em consonância com as directrizes legais - que, topicamente, vão desde a importância, complexidade, urgência, criatividade, resultado, tempo até à responsabilidade -, o cliente deve compreender e aceitar (pagar).

Ainda que se equacione o cenário de uma acentuada dicotomia entre o substancial valor apresentado a título de honorários (calculado atenta a actuação exigente e exímia do advogado) e a manifesta insuficiência financeira da vítima (fruto do contexto vivencial subjacente à violência doméstica condicionar a sua capacidade de pagamento), não se antevê impedimento para a apresentação de uma nota de honorários com um valor final elevado, nem a vítima está exonerada de cumprir a sua obrigação.

Neste tópico, o alerta que se pretende assinalar tem como destinatário, por um lado, as entidades que contribuíram para, até aos dias de hoje, estar em vigor no âmbito do acesso ao direito uma tabela de honorários aprovada em $2004^{108}$. Recorda-se que esta tabela prevê valores de compensação que podem ficar muito aquém de uma remuneração consonante a disponibilidade e competência exigida ao advogado que patrocine uma vítima de violência doméstica ${ }^{109}$. Às mesmas entidades aproveita-se para apelar que é profícua a nomeação do mesmo advogado para acompanhar a vítima nas diversas causas que tenha necessidade de

de seguida, orientar a vítima para o efeito; o advogado pode, ainda, monitorizar (preferencialmente, de modo presencial) a diligência de recolha dos pertences da vítima e, na eventualidade, de ocorrer qualquer entrave ao seu sucesso, deve promover, de imediato, os procedimentos previstos na lei para a vítima efectivar o referido direito.

107 Artigo $105 .^{\circ}$, do EOA,

108 Conferir nota de rodapé n. ${ }^{\circ} 79$.

109 Citam-se, a título de exemplo, duas situações remuneratórias: 25,50€ pela consulta jurídica e 280,50€ pelo processo penal cujo crime seja da competência seja do tribunal singular. 
accionar pelas razões antes expostas, porém o ónus desse patrocínio múltiplo deve, igualmente, proporcionar uma remuneração adequada e, como tal, mais robusta do que o mero somatório das parcelas tabeladas no referido diploma de 2004.

E por outro, dirige-se uma mensagem de apelo ao advogado, que actua no âmbito do acesso ao direito, para reforçar que a aceitação de defesa de uma vítima de violência doméstica seja feita com apreço pela elevada disponibilidade e competência inerente à situação, pelas razões já apontadas. Recomenda-se, assim, a recusa da nomeação para patrocínio oficioso pelo advogado que pretenda somente cumprir "pelo mínimo" as suas obrigações legais e deontológicas. Em respeito pelo sentido de humanismo que a advocacia deve perseguir, não soçobram dúvidas que, se há pessoa que carece de um apoio jurídico extremosamente afincado e balançado para o máximo empenho profissional, uma dessas é a vítima de violência doméstica.

Não se almeja com o presente ensaio justificar-se que a violência doméstica passe a integrar o rol de especialidades da advocacia, embora, a admitir-se futuramente esse cenário, antevê-se que representaria um passo institucional para afirmar a advocacia como profissão baluarte na tutela dos direitos, liberdades e garantias fundamentais da vítima.

É certo que esta prossecução combina, por si só, com o espírito e missão da advocacia, de todo o modo, a dignidade associada a esta nobre profissão está, permanentemente, sujeita a teste. E uma causa desta natureza exige sempre que o advogado abrace afincadamente a tutela da vítima dado que é o caminho necessário percorrer para erradicar a desigualdade, a privação individual e a arbitrariedade que tortura a mesma.

É consabido que são múltiplos os profissionais indispensáveis à assistência e protecção da vítima de violência doméstica. Porém, defende-se que a obtenção do comum sentimento de justiça que a vítima persegue, envolve necessariamente um apoio executado por advogado expertise em violência doméstica. Deve-se, assim, encarar que o caminho rumo à máxima prevenção e repressão de violência doméstica passa pela especialização dos recursos que cooperam para amparar a vítima, inclusive o advogado.

\section{FONTES}

\section{Bibliográfica}

AAVV. - Violência Doméstica - implicações sociológicas, psicológicas ejurídicas do fenómeno - Manual Pluridisciplinar,

Paulo Guerra e Lucília Gago (Coord.), Centro de Estudos Judiciários, Lisboa, 2016, disponível em: http:// www.cej.mj.pt/cej/ recursos/ebooks/outros/Violencia-Domestica-CEJ_p02_rev2c-EBOOK_ver_final.pdf. Albuqueroue, Paulo Pinto de - Comentário do Código Penal à luz da Constituição da República e da Convenção Europeia dos Direitos do Homem. Lisboa: Universidade Católica Editora, 2015.

ALVES, Flávio Santos - «Resposta Organizacionais da PSP em Relação ao Crime de Violência Doméstica». In:

Politeia, ano IX - Edição Especial, Lisboa: ISCPSI, 2012. 
BRANDÃo, Nuno - «Bem Jurídico e Direitos Fundamentais entre a Obrigação Estadual de Protecção e a Proibição do Excesso» In: Estudos em Homenagem ao Prof. Doutor Manuel da Costa Andrade, Coimbra: Instituto Jurídico, 2017.

CAnotilho, Gomes e Moreira, Vital - Constituição da República Portuguesa Anotada - Volume I. $4 .^{\text {a }}$ edição revista, Coimbra: Coimbra Editora, 2007.

CARVAlHo, Emanuel - «Violência doméstica e estrangeiros em Portugal». In: Galileu - Revista de Direito e Economia, Volume XX, 1. ${ }^{\circ}$ semestre 2019.

DiAs, Figueiredo - Comentário Conimbricense do Código Penal - Tomo I. Coimbra: Coimbra Editora, 1999.

Fernandes, Plácido Conde - «Violência Doméstica: novo quadro penal e processual penal». In: Revista do CEJ, n. ${ }^{\circ}$ 8, Lisboa, 2004.

Garcia, M. Miguez e Rio, J. M. Castela - Código Penal Anotado. Coimbra: Almedina, 2015.

MAGALHÃEs, Fernando Sousa - Estatuto da Ordem dos Advogados Anotado. 10. ${ }^{a}$ Edição, Coimbra: Almedina, 2015.

QuARESMA, Carina - «Violência Doméstica: As expetativas das vítimas e o papel das forças de segurança». In: Politeia, ano IX - Edição Especial, Lisboa: ISCPSI, 2014.

Rijo, Daniel e CAPINHA, Marta - «A reabilitação dos agressores conjugais: dos modelos tradicionais de reabilitação ao Programa Português para Agressores de Violência Doméstica (PAVD)». In: Ousar Integrar - Revista de Reinserção Social e Prova. Ano 5, n. ${ }^{\circ}$ 11, Jan. 2012.

SÁ Gomes, Catarina - O Crime de Maus Tratos Físicos e Psíquicos Infligidos ao Cônjuge ou ao Convivente em Condições Análogas às dos Cônjuges. Lisboa: AAFDL, 2004.

Taipa de Carvalho, Américo - «Artigo 152. ${ }^{\circ}$ ». In: Comentário Conimbricense do Código Penal - Tomo I, Coimbra: Coimbra Editora, 1999.

VALENTE, Manuel Monteiro Guedes - Direito Penal do Inimigo e o Terrorismo. Coimbra: Almedina, 2017.

\section{Normativa}

Constituição da República Portuguesa.

Declaração Universal dos Direitos Humanos.

Convenção Europeia dos Direitos do Homem.

Carta dos Direitos Fundamentais da União Europeia.

Convenção do Conselho da Europa para a Prevenção e o Combate à Violência contra as Mulheres e a Violência Doméstica.

Código Civil.

Código Penal.

Código de Processo Penal.

Lei n. ${ }^{\circ}$ 34/2004, 29 de Julho de 2004.

Lei n. ${ }^{\circ}$ 49/2004, 24 de Agosto de 2004.

Lei n. ${ }^{\circ}$ 15/2005, 26 de Janeiro de 2005.

Lei n. ${ }^{\circ} 47 / 2007,28$ de agosto de 2007.

Lei n. ${ }^{\circ}$ 59/2007, 4 de Setembro de 2007.

Lei n. ${ }^{\circ}$ 29/2008, 4 de Julho de 2008.

Lei n. ${ }^{\circ}$ 104/2009, 14 de Setembro de 2009.

Lei n. ${ }^{\circ}$ 112/2009, 16 de Setembro de 2009.

Lei n. ${ }^{\circ}$ 42/2010, 3 de Setembro de 2010.

Lei n. ${ }^{\circ}$ 19/2013, 21 de Fevereiro de 2013(Declaração de Rectificação n. ${ }^{\circ}$ 15/2013, 19 de Março de 2013).

Lei n. ${ }^{\circ} 82-\mathrm{B} / 2014,31$ de Dezembro de 2014.

Lei n. ${ }^{\circ}$ 129/2015, 3 de Setembro de 2015.

Lei n. ${ }^{\circ}$ 145/2015, 9 de Setembro de 2015. 
Lei n. ${ }^{\circ}$ 42/2016, 28 de Dezembro de 2016.

Lei n. ${ }^{\circ}$ 24/2017, 24 de Maio de 2017.

Lei n. ${ }^{\circ}$ 44/2018, 9 de Agosto de 2018.

Lei n. ${ }^{\circ}$ 2/2020, 31 de Março de 2020.

Decreto-Lei n. ${ }^{\circ}$ 132/99, 21 de Abril de 1999.

Decreto-Lei n. ${ }^{\circ} 220 / 2006,3$ de Novembro de 2006.

Decreto-Lei . $^{\circ}$ 120/2010, 27 de Outubro de 2010.

Decreto Regulamentar n. ${ }^{\circ}$ 2/2018, 24 de Janeiro de 2018 (Declaração de Rectificação n. ${ }^{\circ}$ 11/2018, 21 de março de 2018).

Portaria n. ${ }^{\circ}$ 1386/2004, 10 de Novembro de 2004.

Portaria n..$^{\circ}$ 10/2008, 3 de Janeiro de 2008.

Portaria n. ${ }^{\circ} 220-\mathrm{A} / 2010,16$ de Abril de 2010.

Portaria n. ${ }^{\circ} 229-\mathrm{A} / 2010,23$ de Abril de 2010.

Portaria n. ${ }^{\circ}$ 403/2012, 7 de Dezembro de 2012.

Portaria n. ${ }^{\circ}$ 204-B/2013, de 18 de Junho.

Portaria n. ${ }^{\circ} 20-\mathrm{A} / 2014,30$ de Janeiro de 2014.

Portaria n. ${ }^{\circ}$ 20-B/2014, 30 de Janeiro de 2014.

Despacho n. ${ }^{\circ}$ 20509/2008, 5 de Agosto de 2008.

Despacho n. ${ }^{\circ}$ 6810-A/2010, 16 de Abril de 2010.

Despacho n. ${ }^{\circ} 7108 / 2011,11$ de Maio de 2011.

Protocolo n. ${ }^{\circ}$ 17/2000, 22 de Maio de 2000.

Regulamento n. ${ }^{\circ}$ 204/2006, 30 de Outubro de 2006.

Regulamento n. ${ }^{\circ}$ 15/2004, 5 de Abril de 2004.

Regulamento n. ${ }^{\circ}$ 9/2016, 6 de Janeiro de 2016.

Deliberação n. ${ }^{\circ}$ 1004/2016, 20 de Junho de 2016.

\section{Jurisprudencial}

Acórdão do Tribunal da Relação de Coimbra, no processo n. ${ }^{\circ}$ 1290/12.1PBAVR.C1, de 29/01/2004.

Acórdão do Tribunal da Relação de Coimbra, processo. n. ${ }^{\circ}$ 182/06.8TAACN, de 19/11/2008.

Acórdão do Tribunal da Relação de Coimbra, no processo n. ${ }^{\circ}$ 663/16.5PBCTB.C1, de 07/02/2018.

Acórdão do Tribunal da Relação de Guimarães, no processo n. ${ }^{\circ}$ 639/08.6GBFLG.G1, de 15/10/2002.

Acórdão do Tribunal da Relação de Guimarães, no processo n. ${ }^{\circ}$ 2255/15.7T9PRT.P1, de 12/10/2016.

Acórdão do Tribunal da Relação de Guimarães, no processo n. ${ }^{\circ}$ 201/16.06GBBCL.G1, de 06/02/2017.

Acórdão do Tribunal da Relação de Lisboa, no processo n. ${ }^{\circ}$ 3/16.oPAPST.L1-9, de 01-06/2017.

Acórdão do Tribunal da Relação do Porto, processo n. ${ }^{\circ}$ 176/11.1SLPRT.P1, de 26/09/2012.

\section{Outros documentos}

Direcção-Geral de Política de Justiça - Relatório Anual de Segurança Interna de 2018, disponível em: https://www. portugal.gov.pt/download-ficheiros/ficheiro.aspx?v =ad5c fe37-od52-412e-83fb-7fo98448d ba7.

Entidade Reguladora Para a Comunicação Social - Representações da Violência Doméstica nos telejornais de horário nobre, disponível em: https://www.flipsnack.co m/ERCpt/representa-es-viol-ncia-dom-stica-nostelejornais-de-hnobre/full-view.html.

Governo da República Portuguesa - Dados Trimestrais | Violência Doméstica, disponível em: https://www. portugal.gov.pt/download-ficheiros/ficheiro.aspx?v=8edo c295-dic7-4c67-be38-a179413ade57.

União de Mulheres Alternativa e Resposta, Relatório do Observatório de Mulheres Assassinadas de 2018, disponível em: http://www.umarfeminismos.org/images/stories/oma/Relat\%C3\%B3rio_OMA_2019.pdf. 